\title{
Variations in Vegetation Structure, Species Dominance and Plant Communities in South of the Eastern Desert-Egypt
}

\author{
Fawzy SALAMA ${ }^{1 *}$, Monier ABD EL-GHANI ${ }^{2}$, Mohamed GADALLAH ${ }^{1}$, Salah EL- \\ $\mathrm{NAGGAR}^{1}$, Ahmed $\mathrm{AMRO}^{1}$
}

\author{
I Assiut University, Faculty of Science, Botany Department, Assiut University Street, Assiut 71516, Egypt; \\ mohamed.aag2@yahoo.com; salahelnaggar40@yahoo.com;ahmed.amro81@yahoo.com; \\ fawzysalama2010@yahoo.com (*corresponding author) \\ ${ }^{2}$ Cairo University, Faculty of Science, Botany Department, 12613 Giza, Cairo, Egypt; elghani@yahoo.com
}

\begin{abstract}
For two successive years, the floristic diversity and vegetation composition in the southern part of the Eastern Desert of Egypt were investigated through four transects ( 3 crossing the Eastern Desert and one along the Red Sea). The data collected from 142 stands covering the study area included the species composition, functional groups, chorology and occurrences (Qvalues). A total of 94 plant species belonging to 33 different families were recorded, with Asteracea, Zygophyllaceae, Fabaceae, Poaceae, Chenopodiaceae and Brassicaceae as the largest families. Shrubs represented the largest functional group (39.4\%), while perennial herbs represented the smallest ones (12.8\%). Species occurrence (Q-value) revealed that Zilla spinosa, Acacia tortilis subsp. raddiana, Morettia philaeana, Caroxylon imbricatum, Zygophyllum coccineum and Citrullus colocynthis had wide ecological range of distribution (dominant species, Q-values $\geq 0.2$ ). Saharo-Arabian chorotype was highly represented (72.6\%) in the flora of this area, eventually as mono, bi or pluriregional. Classification of the data set yielded 7 vegetation groups included: (A) Zilla spinosa-Morettia philaeana, (B1) Zilla spinosa-Citrullus colocynthis-Morettia philaeana, (B2) Zilla spinosa, (C1) Zygophyllum album-Tamarix nilotica, (C2) Zygophyllum coccineum-Tamarix nilotica, (D1) Zilla spinosa-Zygophyllum coccineum and (D2) Zilla spinosa-Acacia tortilis subsp. raddiana-Tamarix aphylla-Balanites aegyptiaca. Certain vegetation groups were assigned to one or more transects. Detrended Correspondence Analysis (DCA) revealed that electrical conductivity, sodium, potassium, calcium, magnesium, chlorides, moisture content, sulphates, $\mathrm{pH}$, organic matter and gravel were the soil variables that affect the species distribution in this study.
\end{abstract}

Keywords: arid environment, chorology, flora, plant functional groups, soil-vegetation relationships.

\section{Introduction}

The Eastern Desert of Egypt occupies about 223,000 $\mathrm{km}^{2}$, i.e. $21 \%$ of the total area of Egypt. It is characterized by two main ecological units, the Red Sea costal land and the inland desert with its wadis. In Egypt, like in the other arid lands, the desert vegetation is characterized by openness and is composed of a permanent framework of perennials, the interspaces of which may be occupied by ephemerals and their duration depends on the irregular rainfall and soil thickness (Zahran and Willis, 2009). The vegetation composition and plants distribution covering the Egyptian Eastern Desert and Red Sea coast such as in the northern inland part (Abd El-Ghani, 1998; Fossati et al., 1998), in Wadi Allaqi (Sheded et al., 2012), in Wadi Degla (Hegazy et al., 2012), in Wadi Gimal (Galal and Fahmy, 2011; Gomaa, 2012), in Wadi Natash (Suzan et al., 2013) and in central Eastern Desert (Abd El-Ghani et al., 2013a; Salama and El-Naggar, 1991; Salama and Fayed, 1990;
Salama et al., 2012, 2013) have been studied.

Ecologically, this desert is characterized by two main units, the Red Sea costal land and the inland desert. The Red Sea coastal land extends from Suez to Mersa Halaib at the Sudano-Egyptian border, while the inland part lies between the range of the Red Sea coastal land in the east and the Nile Valley in the west (Hassib, 1951). It is a rocky plateau dissected by a number of wadis; each has a main channel with numerous tributaries.

The floristic compositions, life forms and chorological affinities of deserts paid the attention to many others. Along an altitudinal gradient in East Ladakh (NW Himalayas) of India, Klimes (2003) indicated the preponderance of hemicryptophytes followed by therophytes. Also, the main life-form classes in Brazilian (Cerrado sites) were the hemicryptophytes and the phanerophytes (Batalha and Martins, 2002). Therophytes also dominated many arid and semi-arid 
study areas as in northeastern Brazil (Da Costa et al., 2007), in Mount Hymettus of central Greece (Gouvas and Theodoropoulos, 2007), in Khulais region of western Saudi Arabia (Al-Sherif et al., 2013) and in Alborz Mountains of Iran (Mahdavi et al., 2013).

One approach to addressing the complexity of desert vegetation is functional analysis. Plant species can be classified into functional groups based on a variety of characteristics. Functional groups have been defined as sets of species showing either similar responses to the environment or similar effect on major ecosystem processes (Gitay and Noble, 1997). Each functional group potentially will partition the environmental gradient differently (Austin, 1990; Dale, 1998; Lyon and Sagers, 2003; Smith and Huston, 1989).

The availability of water is one of the major factors reglating the species distribution in arid zones that are usually characterized by irregular, scanty and unpredictable rainfall, and long periods of drought (NoyMeir, 1973; Yair and Danin, 1980). Soil-vegetation relationships were the subject of several investigations in the arid regions of the Middle East, e.g., Hillel and Tadmor (1962), Kassas and Girgis (1965), OlsvigWhittaker et al. (1983), Stahr et al. (1985). Recently, multivariate analysis techniques were extensively used to elucidate these relationships, e.g., Moustafa and Zaghloul (1996), Abd El-Ghani (2000) Abd El-Ghani and Amer (2003), Abd El-Ghani et al. (2013 a, b), Salama et al. (2012, 2013).

This study aimed to (1) determine the spatial distribution patterns of the recorded species in terms of plant functional groups, (2) assess the soil factors which controlle the vegetation and to identify the regional plant communities, and (3) analyze the floristic variations between the northern and southern parts of the Eastern Desert.

\section{Materials and methods}

\section{Study area}

The study area covered nearly the southern quarter of the Eastern Desert (about 54,500 $\mathrm{km}^{2}$ ) between 26 $45^{\prime}$ and $24^{\circ} 1^{\prime} \mathrm{N}$ latitudes and $32^{\circ} 45^{\prime}$ and $35^{\circ} 00^{\prime} \mathrm{E}$ longitudes (Fig. 1) It covered the area between Qena Governorate until Aswan Governorate on the Nile Valley and from Safaga until Berenice on the Red Sea coast. According to Zahran and Willis (2009), this area covered three desert types: (1) The limestone desert (Assiut-Qena Desert), (2) The sandstone desert (Idfu-Kom Ombo Desert), and (3) The Red Sea coastal plain. Detailed studies on the geology, geomorphology, topography and lithology have been documented by Said (1962), Abu Al-Izz (1971), and Zahran and Willis (2009).

The Egyptian desert is among the most arid parts of the world characterized by extreme aridity and high temperature. Available climatic records over the period 2003-2012 in four meteorological stations (Qena, Safaga, Aswan and Marsa Alam) demonstrated that the average monthly temperature ranged between $14.9^{\circ} \mathrm{C}$ in January (minimum) and $33.6^{\circ} \mathrm{C}$ (maximum) in July. Rainfall occurs only in winter and is due to random cloudbursts, a general feature in arid desert: rain may occur once every several years. Annual average rainfall records (over 30 years) showed notable decrease along north-south direction: $5.3 \mathrm{~mm} /$ year in Qene in the north along the Nile Valley to $3.4 \mathrm{~mm} /$ year in Quseir in the south along the Red Sea coast (Abd El-Ghani, 1998). Averages of relative humidity reached to the maximum of $51.5 \%$ and $52.7 \%$ (in December), while its minimum reached $25.6 \%$ and $32.4 \%$ (in June) for Mersa Alam and Safaga (Abd ElGhani, 1998, Abd El-Ghani et al., 2013a).

\section{Data collection and vegetation analysis}

Between 2011 and 2012, vegetation sampling was performed in the study area using 4 transects representing the 3 desert types (Fig. 1). One hundred and forty-two georeferenced (using GPS model Garmin eTrex HC) randomly selected stands $(20 \times 30 \mathrm{~m})$ were selected along the four transects to represent apparent variations in the physiognomy of vegetation and in the physiographic features. The sandstone desert included (T1) which comprised of Aswan-Berenice road $\left(300 \mathrm{~km} ; 24^{\circ} 05^{\prime}-24^{\circ} 00^{\prime}\right.$ $\mathrm{N}$ and $\left.32^{\circ} 55^{\prime}-35^{\circ} 24^{\prime} \mathrm{E}\right)$; Wadi Kharit $\left(250 \mathrm{~km}, 24^{\circ} 26^{\prime}\right.$ $24^{\circ} 12^{\prime} \mathrm{N}$ and $\left.33^{\circ} 11^{\prime}-34^{\circ} 40^{\prime} \mathrm{E}\right)$; W. Natash (100 km, 24² $21^{\prime}$ $-24^{\circ} 40^{\prime} \mathrm{N}$ and $\left.33^{\circ} 24^{\prime}-34^{\circ} 30^{\prime} \mathrm{E}\right)$, and W. Gimal (65 km, $24^{\circ} 34^{\prime}-24^{\circ} 40^{\prime} \mathrm{N}$ and $34^{\circ} 35^{\prime}-35^{\circ} 05^{\prime} \mathrm{E}$ ); (T2) Idfu-Marsa Alam road $\left(100 \mathrm{~km}, 25^{\circ} 55^{\prime} \mathrm{N}, 32^{\circ} 55^{\prime}-34^{\circ} 55^{\prime} \mathrm{E}\right)$. In the limestone desert, (T3) included Qena-safaga road $(155 \mathrm{~km}$, $26^{\circ} 12^{\prime}-26^{\circ} 46^{\prime} \mathrm{N}$ and $\left.32^{\circ} 44^{\prime}-33^{\circ} 56^{\prime} \mathrm{E}\right)$, and along the Red Sea coastal plain (T4) that extends for about $240 \mathrm{~km}$ between $24^{\circ} 39^{\prime}-26^{\circ} 36^{\prime} \mathrm{N}$ and $32^{\circ} 05^{\prime}-34^{\circ} 00^{\prime} \mathrm{E}$.

In this study, plants were categorized into four functional

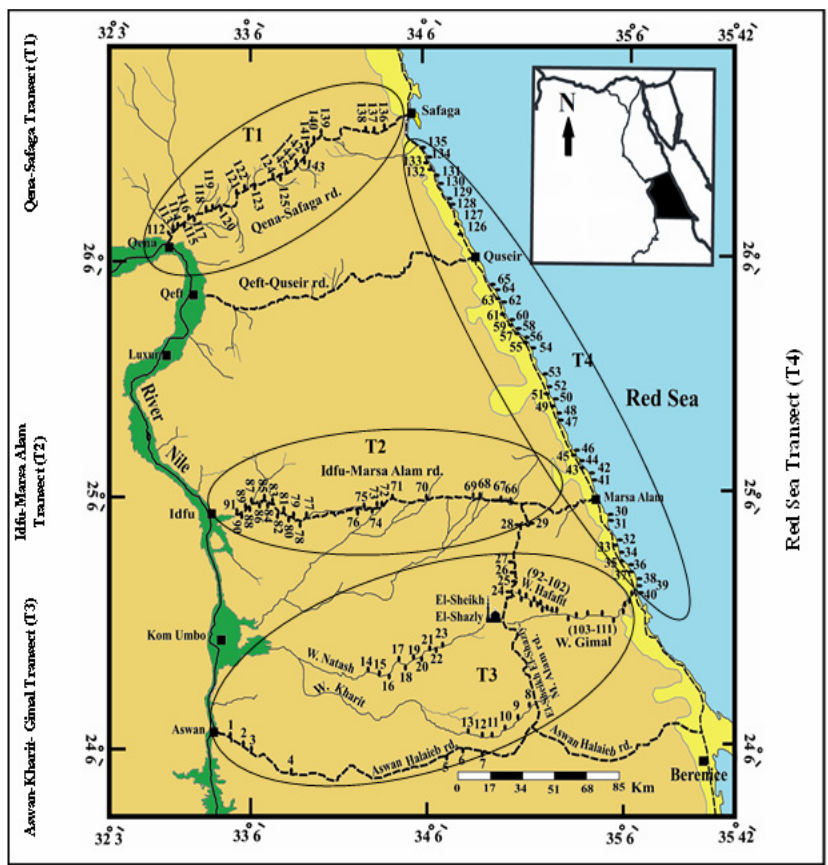

Fig. 1. Location map of the study area, showing the distribution of the studied stands along the 4 transects 
43

groups: trees, shrubs, perennial herbs and annual herbs. Correspondingly, in each transect plant species were segregated into four a priori defined functional groups: tree layer species, shrub layer species, and herb species. The presence/absence for each species was recorded in the studied stands, and a count-floristic list was obtained. The number of species within each functional group category was expressed as a percentage of total number of species in each transect. Analysis of phytogeographical ranges was carried out according to White and Léonard (1991). Taxonomic nomenclature and functional groups categorizing was according to Täckholm (1974), Boulos (1995, 1999, 2000, 2002, 2005) and El Hadidi and Fayed $(1978,1995)$. Voucher specimens of each species were collected, and identified at the Herbaria of Assiut University (ASTU) and Cairo University (CAI), where they were deposited.

The degree of occurrence of each species was determined using the Q-value (Danin et al., 1985) as follows: $\mathrm{Q}=$ number of entries of a species $\mathrm{X}$ total number of species/13,348 (total number of entries). The $Q$-values and occurrences were categorized as follows: $\mathrm{D}=$ dominant, $\mathrm{Q}$-value $\geq 0.2 ; \mathrm{VC}=$ very common, $\mathrm{Q}$ value $0.1-0.199 ; \mathrm{C}=$ common, $\mathrm{Q}$-value $0.05-0.099$; $\mathrm{O}=$ occasional or rare species, $\mathrm{Q}$-value $0.01-0.049$ and $\mathrm{S}=$ sporadic or very rare, $\mathrm{Q}$-value $\leq 0.01$.

A floristic presence-absence data matrix of 142 stands and 94 species was subjected to classification by cluster analysis of the program Community Analysis Package (CAP) version 1.2 (Henderson and Seaby, 1999) using squared Euclidean distance dissimilarity matrix with minimum variance (also called Ward's method) as agglomeration criterion (Orlóci, 1978). The resulted vegetation groups (plant communities) were named after the dominant species that have the highest presences percentages in the stands of this group.

Detrended Correspondence Analysis (DCA) ordination based on species presence-absence data for each species was performed to examine patterns in species composition among species of different vegetation groups. The relationship between the vegetation and soil variables were assessed by calculating the simple linear correlation coefficient ( $r$ ) between the DCA axes (reflect the vegetation gradient) and the soil variables.

One Way Analysis of Variance was applied to examine the statistical differences between the functional groups.

\section{Soil sampling and analysis}

Soil samples $(0-50 \mathrm{~cm}$ depth) were collected at 3 random points from each stand as a profile (composite samples). These samples were then air-dried, thoroughly mixed, and pass through a $2 \mathrm{~mm}$ sieve to get rid of gravel and boulders. The weight of gravel in each stand was determined and expressed as a percentage of the total weight of the soil sample. The soil texture was determined using the sieve method; the amount of each fraction (sand, silt and clay) was expressed as percentage of the original weight used (Ryan et al., 1996). Soil moisture content was estimated by drying at $105^{\circ} \mathrm{C}$; then the percentage of soil moisture was calculated based on dry weight of the soil (Kapur and Govil, 2000). The soil portion less than $2 \mathrm{~mm}$ in size was kept for chemical analysis according to Jackson (1967) and Allen and Stainer (1974). Soil water extracts (1:5) were prepared for determination of electrical conductivity (EC) using conductivity meter, and $\mathrm{pH}$ using a glass electrode $\mathrm{pH}$ meter. Organic matter (OM) was determined using the Walkely and Black rapid titration (Black, 1979). Sodium and potassium were determined by flamephotometer. Calcium and magnesium were estimated by titration against EDTA (ethylenediamine dihydrogen tetraacetic acid) using ammonium purpurate and eriochrome black $\mathrm{T}$ as indicators (Jackson, 1967). Chlorides were determined by direct titration against $\mathrm{AgNO}_{3}$ using potassium chromate as an indicator, and bicarbonates by direct titration against $\mathrm{HCl}$ using methyl orange as indicator. Sulphates were determined by a turbidemetric technique with barium chloride and acidic sodium chloride solution using spectrophotometer (Model 1200) according to Bardsley and Lancaster (1965).

\section{Results}

\section{Floristic composition}

In total, 94 species (62 perennials and 32 annuals) constituted the floristic composition, representing 76 genera and 33 families (Tab. 1). About more than $50 \%$ of these species belonged to 6 families arranged in the following sequence, Asteraceae > Zygophyllaceae > Fabaceae $>$ Poaceae $>$ Chenopodiaceae $>$ Brassicaceae. The largest family was Asteraceae (7 genera and 10 species), while 18 families were monospecific. The total number of recorded species was 46, 35, 52 and 46 for T1, T2, T3 and T4, respectively.

In terms of functional groups (Fig. 2), it can be noted that trees and perennial herbs were the least (2-7 species) represented among the 4 studied transect, while annual herbs and shrubs were the most (14-24 species). The distribution of functional groups within the studied transects showed significant difference (F-value $=3.11$, $\mathrm{P}=0.032$ ) for the Red Sea transect (T4) among the others (F-value $=0.92, \mathrm{P}=0.44, \mathrm{~F}$-value $=0.51, \mathrm{P}=0.68$, and $\mathrm{F}$ value $=0.65, \mathrm{P}=0.58$ for $\mathrm{T} 1, \mathrm{~T} 2$ and $\mathrm{T} 3$, respectively). Few grasses (Poaceae) were recorded within transects (5, $2,1,5$ species in $\mathrm{T} 1, \mathrm{~T} 2, \mathrm{~T} 3$ and $\mathrm{T} 4$, respectively), whereas shrubs dominated $(17,14,20$ and 23 species in $\mathrm{T} 1, \mathrm{~T} 2, \mathrm{~T} 3$ and $\mathrm{T} 4$, respectively).

Tab. 1 showed the distribution of the different functional groups within the study area. The recorded 13 tress were, amongst others, Acacia tortilis subsp. raddiana, Tamarix aphylla, Balanites aegyptiaca, Ziziphus spinachristi, Avicennia marina, Hyphaene thebaica, and Moringa peregrina.

Shrubs were the largest (37 species) represented functional group. The widely distributed species included Zygophyllum coccineum, Zilla spinosa, Caroxylon imbricatum, Aerva javanica and Leptadenia pyrotechnica that occurred in all transects. Whereas Caroxylon villosum, Artemisia judaica, Atriplex leucoclada, Chrozophora oblongifolia, Fagonia mollis and $F$. bruguieri were represented only in the northern transect (T1), 
Zygophyllum album, Nitraria retusa, Limonium axillare, Arthrocnemum macrostachyum, Cornulaca monacantha, Taverniera aegyptiaca and Capparis spinosa were confined to the Red Sea transect (T4), and another 3 shrubs showed consistency to the southern sector (AswanKharit-Gimal transect; T3).

Four perennial herbs (Aeluropus littoralis, Juncus rigidus, Leptochloa fusca and Cyperus rotundus) showed consistency to the Red Sea transect (T4). For the northern transect (T1), Imperata cylindrica, Stipagrostis plumosa, Dichanthum annulatum and Typha domingensis exhibited certain degree of consistency to this transect (Tab. 1).

Three annual herbs (Astragalus vogelii, Polycarpaea repens and Tetraena simplex) had wide range of distribution (occurred in all transects). The AswanKharit-Gimal transect (T3) was characterized by Astragalus eremophilus, Hippocrepis constricta, Lupinus digitatus, Launaea amal-aminae, L. capitata, Polycarpaea robbairea and Glinus lotoides which were not recorded elsewhere (Tab. 1).

\section{Species abundance}

The recorded species were categorized according to their Q-values (Tab. 1) as follwos: (i) Dominant species, of which Zilla spinosa had presence value of $61 \%$, and Acacia tortilis subsp. raddiana with $\mathrm{P}=36 \%$. Caroxylon imbricatum and Zygophyllum coccineum (shrubs), Morettia philaeana (annual herb) and Citrullus colocynthis (perennial herb) had lower presence values; (ii) Very common species, 10 species (e.g., Tamarix aphylla, Fagonia thebaica, Aerva javanica, Pulicaria undulata, Schouwia purpurea); (iii) Common species, 20 species included some salt-tolerant species such as Nitraria retusa and Zygophyllum album, and Phragmites australis; (iv) Occasional species, constituted the main bulk of the flora (33 species, $35.1 \%$ of total species), with their Q-values ranged between 0.01 and 0.049; (v) Sporadic species, comprised of 25 species with Qvalues $=0.007$ which included 4 trees, 7 shrubs, 6 perennial herbs and 8 annual herbs.

\section{Chorological affinities}

The chorological spectrum of the recorded species was illustrated in Fig. 2. The cosmopolitan, palaeotropical and pantropical species constituted 12 species $(12.8 \%$ of the total flora - Tab. 1). Monoregional Saharo-Arabian chorotype was well-represented ( 35 species) in the study area, while species of Sudano-Zambezian (Crotalaria aegyptiaca), Sudanian (Acacia nilotica), Mediterranean (Lotus hebranicus and Lupinus digitatus) and IranoTuranian (Cotula cinerea) were very modestly represented.

A total of 30 species were bi-regional chorotypes representing $31.9 \%$ of the recorded species, distributed as follows: (1) 18 species belonging to SaharoArabian+Sudano-Zambezian (e.g., Trichodesma africanum, Balanites aegyptiaca, Leptadenia pyrotechnica, Calotropis procera, Cleome amblyocarpa, Salvadora persica, Limonium axillare and Hyphaene thebaica). (2) 7 species belonging to the Saharo-Arabian+Irano-Turanian (e.g., Tamarix aphylla, Launaea nudicaulis, Cleome droserifolia and Fagonia bruguieri, (3) 2 species belonging to SudanoZambezian+Guineo-Congo (Moringa peregrina and Oxystelma esculentum), (4) 1 species belonging to Mediterranean+Irano-Turanian (Aeluropus littoralis). (5) 2 species belonginig to Mediterranean+SaharoArabian (Panicum turgidum and Chrozophora oblongifolia). In general, 18 species were belonged to Saharo-Arabian+Sudano-Zambezian, while the SaharoArabian+Irano-Turanian species were represented by 7 species (Tab. 1).

About $12.8 \%$ of the recorded species (12 species) were pluri-regional with wide geographical range of distribution (e.g., Citrullus colocynthis, Zygophyllum album, Arthrocnemum macrostachyum, Juncus rigidus and Capparis spinosa).

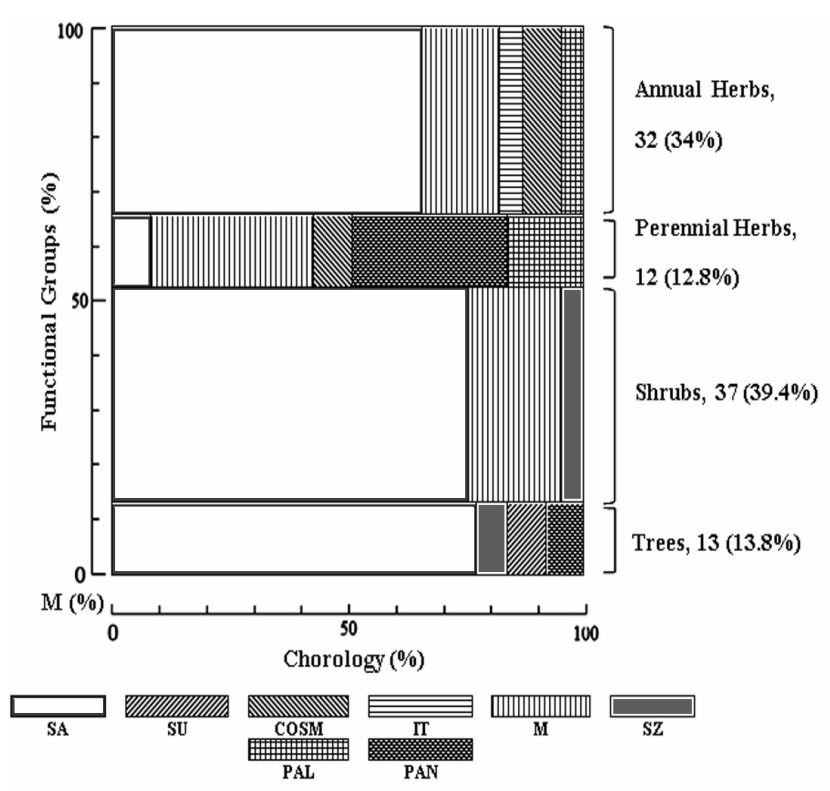

Fig. 2. Chorotype spectrum and functional groups diagram of the study area. $M=$ species magnitude and average group abundance

\section{Classification of the vegetation}

Application of classification using cluster analysis to the floristic presence-absence data matrix of the study area yielded 7 vegetation groups (Tab. 2, Fig. 3). Each of the identified vegetation group will be named after the dominant species (i.e., highest presence percentages). Notably, none of the recorded species occurred in all the identified groups. Apart from coarse sand, clay and bicarbonates, the other thirteen (out of total of 16) measured soil variables showed significant differences ( $\mathrm{p}$ $<0.05,0.01$ ) between the vegetation groups (Tab. 3).

Group (A): Zilla spinosa-Morettia philaeana group

The 18 stands of this group (41 species) were mostly located along Idfu-Marsa Alam transect (T2), with soil soil rich in its organic matter $(\mathrm{OM})$ content and and highest $\mathrm{pH}$, but had the lowest contents of fine sand, 
45

water content, $\mathrm{Mg}^{+2}$ and $\mathrm{Cl}$. Co-dominant species included Caroxylon imbricatum, Fagonia thebaica, Schouwia purpurea and Tetraena simplex. Consistent species to this group were Echium horridum, Glinus lotoides, Oxystelma esculentum, Caroxylon villosum, Stipagrostis plumosa and Tribulus megistopterus.

Group (B1): Zilla spinosa-Citrullus colocynthisMorettia philaeana group

The 18 stands of this group (26 species) were located along Wadi Natash, W. Kharit and El-Shekh El-ShazlyMarsa Alam road (T3). Soil contents of gravels, fine sand, $\mathrm{OM}$ and $\mathrm{pH}$ were higher than the total means. The lowest contents were recorded in $\mathrm{Na}^{+2}$ and $\mathrm{HCO}_{3}$. Beside the dominants, Acacia tortilis subsp. and Senna italica were the co-dominants. Some species were confined to this group such as Chenopodium album and Filago desertorum.

Group (B2): Zilla spinosa group

This group (7 stands, 30 species) was characterized by the dominance of Zilla spinosa $(\mathrm{P}=100 \%)$, distributed along (Aswan-Kharit-Gimal transect, T3). Most of the examined soil variables (gravels, clay, $\mathrm{EC}, \mathrm{OM}, \mathrm{Na}^{+}, \mathrm{K}^{+}$, $\mathrm{Ca}^{+2}, \mathrm{HCO}_{3}^{-}$and $\mathrm{SO}_{4}^{-2}$ ) attained their lowest levels in the stands of this group. However, fine sand content was the highest amongst the others. Among the important co-dominant species, Astragalus vogelii, Cotula cinerea and Launaea nudicaulis were included. Consistent species to this group were Launaea capitata and $L$. cassiniana. group

Group (C1): Zygophyllum album-Tamarix nilotica

Most stands of this group (41 stands, 32 species) were located along the Red Sea coast transect (T4) between Marsa Alam and Qusier, and occurred on saline soil with soluble anions and cations contents higher than the groups (A, B1, B2, D1 and D2). The dominant species of this group, together with the co-dominants Nitraria retusa and Limonium axillare exhibited the saline nature of this group. Certain species showed consistency to this group such as Aeluropus littoralis, Arthrocnemum macrostachyum, Avicennia marina.

Group (C2): Zygophyllum coccineum-Tamarix nilotica group

This group (8 stands) was the least diversified (19 species) among others. The stands of this group were mainly located in T4 (Qusier-Safaga transect) along the Red Sea coast occurred on saline soil with the highest silt, clay, electric conductivity, water content and all the examined ions. However, it recorded the lowest $\mathrm{pH}$ and coarse sand content. The co-dominant species included Phragmites australis, Nitraria retusa, Limonium axillare and Zygophyllum album. Four weed species (Chenopodium murale, Cyperus rotundus, Leptochloa fusca and Sonchus oleraceus) were recorded among the 6 confined species to this group.

Group (D1): Zilla spinosa-Zygophyllum coccineum group

This group of stands (31) was the most diversified ( 53 species) among other groups, and collected from three different transects (T1, T2 and T4) found on soil in rich in gravels and poor in silt content. The other soil factors had intermediate position amongst the other groups. The co-dominant species included Caroxylon imbricatum, Lotus hebranicus and Ochradenus baccatus. Twelve species showed consistency to this group such as Acacia nilotica, Moringa peregrina, Ziziphus spina-christi (trees), Atriplex leucoclada, Fagonia bruguieri (shrubs), and Dichanthum annulatum, Imperata cylindrica (herbs).

Group (D2): Zilla spinosa-Acacia tortilis subsp.Tamarix aphylla-Balanites aegyptiaca group

This group (19 stands, 20 species) was characterized by the combination of the dominant species, mostly located in Wadi Gimal and its tributaries (T3) on a soil rich in fine sand, silt, $\mathrm{pH}$ and $\mathrm{K}^{+}$and poor in $\mathrm{Mg}^{+2}$ and water contents. The co-dominants of this group had low presence values such as Zygophyllum coccineum, Pulicaria undulata and Calotropis procera. Two species were confined to this group, Capparis decidua and Salvadora persica.

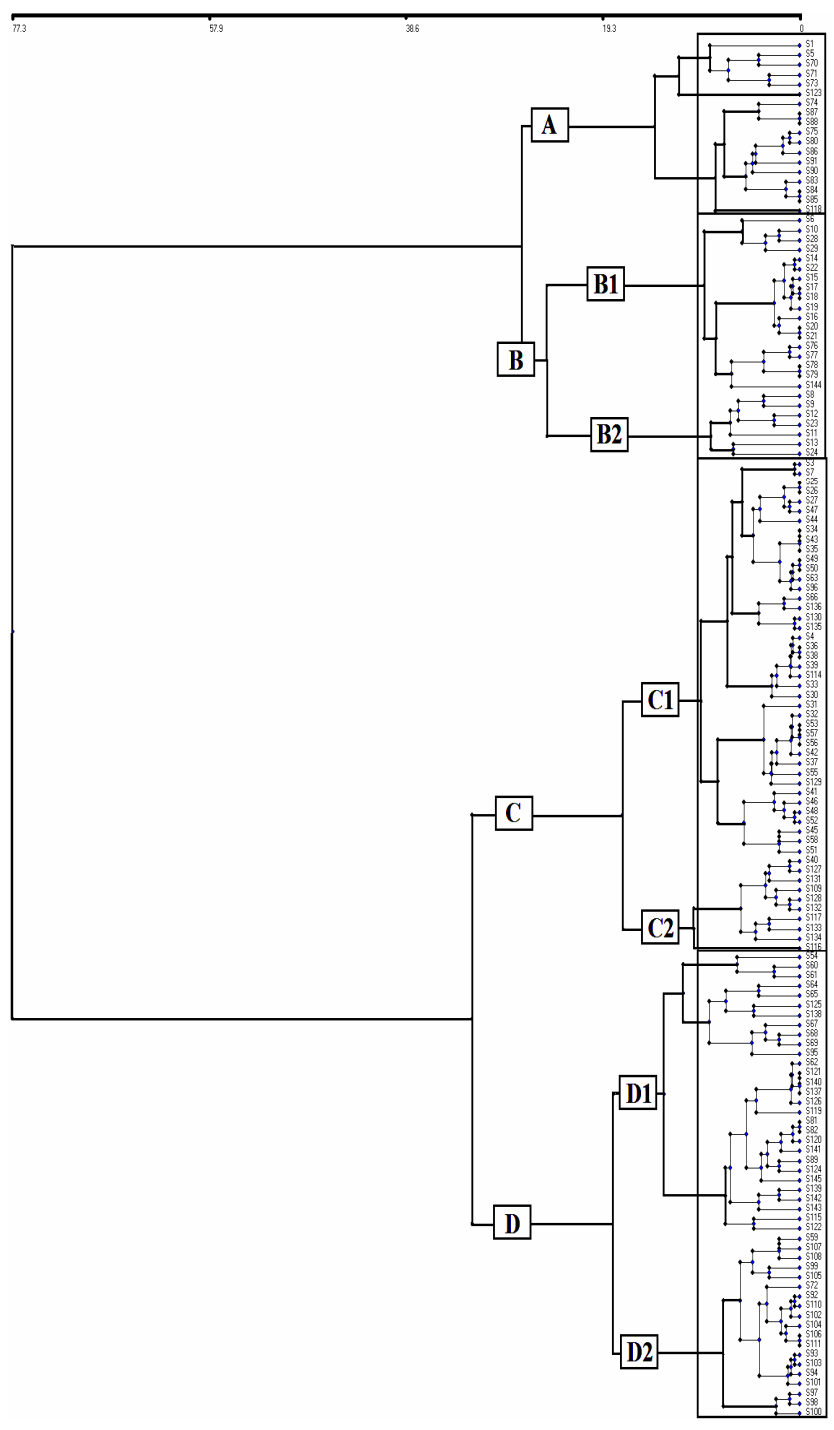

Fig. 3. Dendrogram showing cluster analysis of the studied 142 stands, with the 7 vegetation groups (A-D2) separated. 


\section{Ordination of the vegetation}

Analysis of 142 stands along axes 1 and 2 (eigenvalues 0.707 and 0.497 , respectively) by DCA confirms the classification results, where the 7 vegetation groups were also segregated (Fig. 4). Linear response models were dropped because gradients along the first two axes were longer than 4 SD units (Jongman et al., 1987). The length of gradient represented by axis 1 was $>9 \mathrm{SD}$, indicating a complete turnover in species composition along this gradient. Therefore, DCA was the appropriate ordination method or indirect gradient analysis to be used. The four DCA axes explained 5.3\%, 3.7\%, 2.8\% and $2.6 \%$ of the total variation in the species data, respectively. This low percentage of variance explained by the axes was attributed to the many zero values in the vegetation data set. It can be observed that the eigenvalue for the first DCA axis was high, indicating that it captured the greater proportion of the variation in species composition among stands. It is clear that group $\mathrm{C} 1$ occupied the positive end of the first DCA axis, while groups B1 and B2 occupied the negative end. This arrangement may explain a gradient of increasing soil salinity and moisture content (Tab. 4), where stands of group $\mathrm{C} 1$ were located along the Red Sea coast transect, while B1 and B2 in the inland desert of Wadi GimalAswan-Wadi Kharit transect. The first DCA axis was positively correlated with electrical conductivity $(\mathrm{r}=0.297)$, sodium $(\mathrm{r}=0.342)$, potassium $(\mathrm{r}=0.307)$, calcium $(\mathrm{r}=0.296)$, magnesium $(\mathrm{r}=0.318)$, chlorides $(\mathrm{r}=$ $0.217)$, moisture contents $(\mathrm{r}=0.418)$ and sulfates $(\mathrm{r}=0.612)$, and negatively with $\mathrm{pH}(\mathrm{r}=-0.167)$ and gravels $(\mathrm{r}=-0.249)$. The second axis was positively correlated with sulfates $(\mathrm{r}=0.172)$ and organic matter $(\mathrm{r}=0.218)$.

\section{Comparison between northern and southern parts of Eastern Desert}

Tab. 5 displayed the floristic composition between two geographically distant $(253 \mathrm{~km})$ parts (northern and southern) of the Eastern Desert. Whereas the southern part represented by the 4 transects included in this study, the northern part (c. $28,800 \mathrm{~km}^{2} ; 30^{\circ} 05^{\prime}-28^{\circ} 21^{\prime} \mathrm{N}$ and $\left.31^{\circ} 20^{\prime}-33^{\circ} 50^{\prime} \mathrm{E}\right)$ included three transects; Cairo-Suez (T1N; 112 species), Korimat-Zaafarana (T2N; 111 species) and Sheikh Fadl-Ras Gharib (T3N; 54 species) mainly in the limestone part of this desert (Abdel-Aleem, 2013). Altogether, 60 species were in common, 103 species confined to the northern part, and 34 to the southern part.

Four trees: Acacia tortilis subsp. raddiana, Tamarix aphylla, T. nilotica and Calotropis procera exhibited a wide range of distribution as they recorded in the northern and southern parts. While 9 tree species confined to the southern part, and do not penetrate northwards (e.g., Avicennia marina, Hyphaene thebaica, Balanites aegyptiaca, Moringa peregrina), the northern part devoid of any characteristic tree species. Twentyeight shrubby species were recorded in both areas and included amongst others: Zilla spinosa, Zygophyllum coccineum, Caroxylon imbricatum, Suaeda monoica, Zygophyllum album and Pulicaria incisa. Whereas 33 species were confined to the northern part, 9 species characterized the southern part. Perennial herbs were represented by 19 species (Tab. 5), of which 6 were in common (e.g., Phragmites australis, Citrullus colocynthis, Stipagrostis plumosa), 7 species showed consistency to northern part (e.g., Lavandula stricta, Lasiurus scindicus, Aeluropus lagopoides), and 6 species to the southern part (e.g., Juncus rigidus, Aeluropus littoralis) which inhabited wet and saline habitats. The annual herbs (96 species) constituted the major component of the floristic diversity and structure; 22 were in common, 64 species confined to the northern part and 10 species confined to the southern. The northern part included Conyza bonariensis, Emex spinosa, Phalaris paradoxa, Lolium perenne, Cichorium endivia, Amaranthus viridis, Spergularia marina and Avena fatua which are among the common weeds of the Egyptian arable lands.

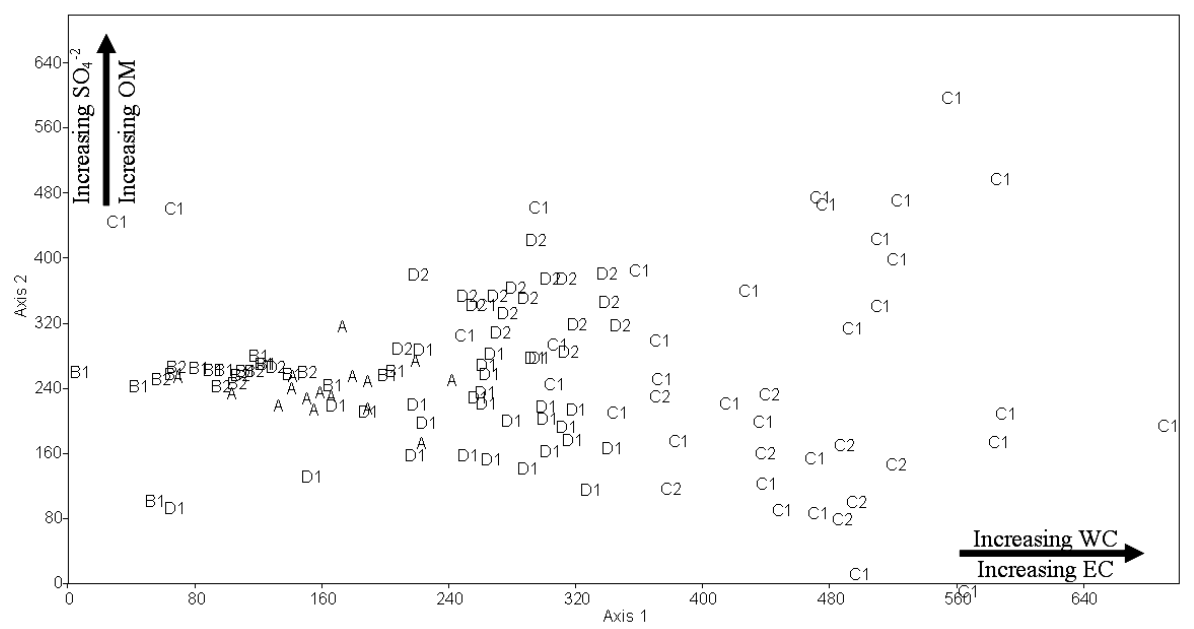

Fig. 4. First two axes of the DCA ordination of 142 stands with the 7 vegetation groups (A-D2) separated by cluster analysis superimposed. 
47

\section{Discussion}

The classification and ordination analyses proposed that the vegetation of the study area can be divided into 7 major vegetation groups (plant communities). The members of each pair of groups are, in some cases, linked together by having one of the dominant species in common. It can be noted that certain vegetation groups characterized one or more of the studied transects; group (A) in Idfu-Mersa Alam transect (T2), groups (B1), (B2) and (D2) in Aswan-Kharit-Gimal transct (T3), groups (C1) and (C2) in Qusier-Safaga transect along Red Sea coast (T4), and group (D1) was widely distributed in the study area including T1, T2 and T4. It can be noted that the salt-tolerant plant Tamarix nilotica characterized vegetation group (C1) and (C2) form hillocks of huge sizes, and vigorously growing southwards (Springuel et al., 1991) representing the natural climax community type of the desert wadis with deep deposits and an underground water reserve (Kassas and Zahran, 1962). Tamarix has been identified as a major cause of salt accumulation on the soil surface (Springuel and Ali, 1990), and concentrating a high amount of sodium chloride in specialized glands within its leaves (Bosabalidis, 1992). In addition, there is a relationship between the amount of Tamarix litter and the electric conductivity of soil (Briggs et al., 1993). Meanwhile, the lower number of recorded species in vegetation group (C1) inhabiting the coastal plains of the Red Sea may be related to its high soil salinity. Such salinity stress on floristic diversity in the study area and related areas was reported by Moustafa and Klopatek (1995) and Shaltout et al. (1997). Most of the identified vegetation groups have very much in common with that recorded in some wadis of the Eastern Desert (Salama et al., 2012, 2013), Western Desert (Abd El-Ghani, 2000; Bornkamm and Kehl, 1990), in south Sinai region (Moustafa and Zaghloul, 1996) and in northwestern Negev, Israel (Tielbörger, 1997).

In extreme deserts, as in the study area, the plant growth is triggered mainly by rain, and thus is as scarce and unpredictable as the precipitation itself. Vegetation develops in 'contracted mode' (Monod, 1954) only in habitats receiving runoff water including wadis, depressions and channels- contracted desert (Shmida, 1985). This highly dynamic vegetation is neither permanent nor seasonal, but is accidental (Bornkamm, 2001; Bullard, 1997; Kassas, 1966). The vegetation structure in the study area is relatively simple, in which the species have to withstand the harsh environmental conditions. This it can be reflected by the presence of several highly adapted, drought-resistant species. The floristic diversity of the study area included 94 species of the vascular plants (67 perennials and 27 annuals) indicating the predominance of perennials. Asteraceae, Fabaceae, Poaceae, Zygophyllaceae and Chenopodiaceae were the species-rich families which formed the major component of the flora. The first three families represent the most common in the Mediterranean North African flora (Quézel, 1978; White, 1993). These findings were in line with those of Salama et al. $(2012,2013)$ in the
Eastern Desert, and Abd El-Ghani and Fahmy (1998) in south Sinai, and Salama et al. (2005) along the western Mediterranean coast.

Chorological analysis revealed that the SaharoArabian element (37.2\% monoregional, $28.7 \%$ biregional, $11.7 \%$ as pluriregional floras) forms the major component of the floristic structure along the four transects. That is because the study area lies within the Saharo-Arabian region of the Holarctic Kingdom (White, 1993). The results were in agreement with those of El-Demerdash et al. (1990), Fossati et al. (1998) and Salama et al. (2012) who concluded that plants of Saharo-Arabian region constituting the shrub layer as good indicators for desert environmental conditions, while species of Mediterranean origin (either mono, bi or pluriregional) flourish in more mesic conditions.

Comparing the results of floristic diversity in the study area (south of the Eastern Desert) with that in the northern part (Abdel-Aleem, 2013) indicated that 60 species were in common, 103 confined to the northern part, while 34 species were consistent to the southern part. So, the floristic diversity in the northern part is three times higher than that of the southern part of the Eastern Desert, which may be attributed to the mild climatic conditions prevailing in the north. Also, increasing the aridity southwards plays a paramount role in reducing floral diversity. On the other hand, 60\% of the northern vegetation (not present in south) was represented as annual herbs. Decreased numbers of annuals in the southern part of the Eastern Desert can be attributed to the environmental aridity and thermal continentality which increases from north to south (Abd El-Ghani, 1998).

Vast areas in the Egyptian deserts (Western, Eastern, and Sinai) were subjected to land reclamation due to increased population growth (Biswas, 1993). In the study area, agricultural processes were practiced in the deltaic parts of several wadis such as Wadi Kherit, W. Natash and W. El-Shikh. As the land reclamation processes entail an almost complete change of the environmental factors, several common weeds of the agro-ecosystem were recorded (e.g., Cynodon dactylon, Malva paviflora, Dicanthiun annulatum, Cyperus rotundus, Sonchus oleraceus and Chenopodium murale). Thus, weeds find the new conditions favorable for their growth. Close to the boundaries of the desert in this study, xerophytic species naturally grow among the weeds of the cultivation. This indicated that these species are native to the natural desert vegetation and can remain after the reclamation process. Therefore, the reclaimed lands found at the desert outskirts can be considered as transitional areas of the succession process between the old cultivated lands and that of the desert (Abd El-Ghani et al., 2013b; Shaheen, 2002).

As for species abundance, Zilla spinosa, Acacia tortilis subsp. raddiana, Morettia philaeana, Zygophyllum coccineum, Caroxylon imbricatum and Citrullus colocynthis (especially in Wadi Natash) had the highest $\mathrm{Q}$-Values $(\mathrm{P}=0.61,0.36,0.3,0.23,0.22$, and $0.21 \%$, respectively). This result was in line with that obtained by Abd El-Ghani et al. (2013a) and Salama et al. (2012) 
in northern and central parts of the Eastern Desert, and Springuel et al. (2006) in the south-eastern part of this desert. Acacia tortilis subsp. raddiana, Morettia philaeana and Citrullus colocynthis were completely absent in Red Sea transect, while the presence of the salttolerant species such as Tamarix nilotica, Limonium axillare, Arthrocnemum macrostachyum, Juncus rigidus and Nitraria retusa with high presence values in the Red Sea transect indicated its salinized habitat. The record of Avicennia marina dominating the mangal vegetation along the Red Sea coast (T4) is notable, and was documentd by Zahran and Willis (2009).

Tab. 1. Species composition of the 4 transects classified according to the different functional groups, together with their presence values (P\%), chorology, Q-values and occurrences. T1 = Qena-Safaga transect; T2= Idfu-Marsa Alam transect; T3= Aswan-Kharit-Gimal transect and T4= Red Sea transect. Choro= Chorology ( $\mathrm{SA}=$ Saharo-Arabian, $\mathrm{SZ}=$ Sudano-Zambezian, $\mathrm{M}=$ Mediterranean, $\mathrm{IT}=$ Irano-Turanian, $\mathrm{ES}=$ Euro-Siberian, $\mathrm{SU}=\mathrm{Sudanian}, \mathrm{GC}=\mathrm{Gueno}-\mathrm{Cungo}, \mathrm{COSM}=$ Cosmopolitan, $\mathrm{PAN}=$ Pantropical, $\mathrm{PAL}=$ Palaeotropical $).$ Occ= Occurrence $(\mathrm{D}=$ Dominant, $\mathrm{VC}=$ Very common, $\mathrm{C}=\mathrm{Common}, \mathrm{O}=\mathrm{Occ}$ asional, $\mathrm{S}=\mathrm{Sporadic})$

\begin{tabular}{|c|c|c|c|c|c|c|c|}
\hline \multirow{2}{*}{ Species } & \multicolumn{4}{|c|}{ p\% for each transect } & \multirow{2}{*}{ Choro } & & \multirow{2}{*}{ Occ } \\
\hline & T1 & $\mathbf{T} 2$ & T3 & T4 & & & \\
\hline 1 & 2 & 3 & 4 & 5 & 6 & 7 & 8 \\
\hline \multicolumn{8}{|l|}{ Species present in all transects } \\
\hline \multicolumn{8}{|l|}{ Shrubs } \\
\hline Zilla spinosa (L.) Prantl. & 81.8 & 96.4 & 73.9 & 15.2 & SA & 0.61 & $\mathrm{D}$ \\
\hline Zygophyllum coccineum $\mathrm{L}$. & 59.1 & 3.6 & 8.7 & 30.4 & SA & 0.23 & $\mathrm{D}$ \\
\hline $\begin{array}{c}\text { Caroxylon imbricatum (Forssk.) Akhani } \\
\text { \& E. H. Roalson }\end{array}$ & 45.5 & 67.9 & 2.2 & 2.2 & SA & 0.22 & $\mathrm{D}$ \\
\hline Lotus hebranicus Hochst. ex Brand & 13.6 & 14.3 & 17.4 & 13 & M & 0.15 & $\mathrm{VC}$ \\
\hline Aerva javanica (Burm. F.) Juss ex Schult. & 18.2 & 25 & 8.7 & 4.3 & SA & 0.12 & $\mathrm{VC}$ \\
\hline Leptadenia pyrotechnica (Forssk.) Decne. & 18.2 & 7.1 & 6.5 & 2.2 & $\mathrm{SA}+\mathrm{SZ}$ & 0.07 & $\mathrm{C}$ \\
\hline \multicolumn{8}{|l|}{ Annual Herbs } \\
\hline Astragalus vogelii (Webb.) Bornm. & 9.1 & 21.4 & 13 & 6.5 & SA & 0.12 & $\mathrm{VC}$ \\
\hline Tetraena simplex (L.) Beier \& Thulin & 9.1 & 28.6 & 8.7 & 2.2 & $\mathrm{SA}+\mathrm{SZ}$ & 0.11 & $\mathrm{VC}$ \\
\hline $\begin{array}{c}\text { Polycarpaea repens (Forssk.) Asch. \& } \\
\text { Schweinf. }\end{array}$ & 4.5 & 3.6 & 4.3 & 6.5 & SA & 0.05 & $\mathrm{C}$ \\
\hline \multicolumn{8}{|l|}{ Species present in three transects } \\
\hline \multicolumn{8}{|l|}{ Trees } \\
\hline $\begin{array}{c}\text { Acacia tortilis (Forssk.) Hayne subsp. } \\
\text { raddiana (Savi) Brenan }\end{array}$ & 0 & 46.4 & 65.2 & 17.4 & SA & 0.36 & $\mathrm{D}$ \\
\hline Tamarix aphylla (L.) H. Karst. & 0 & 10.7 & 26.1 & 17.4 & $\mathrm{SA}+\mathrm{IT}$ & 0.16 & VC \\
\hline T. nilotica (Ehreub.) Bunge & 18.2 & 0 & 4.3 & 30.4 & $\mathrm{SA}+\mathrm{IT}$ & 0.14 & $\mathrm{VC}$ \\
\hline Calotropis procera (Aiton) W. T. Aiton & 4.5 & 7.1 & 6.5 & 0 & $\mathrm{SA}+\mathrm{SZ}$ & 0.04 & $\mathrm{O}$ \\
\hline \multicolumn{8}{|l|}{ Shrubs } \\
\hline Fagonia thebaica Boiss. & 18.2 & 46.4 & 0 & 2.2 & SA & 0.13 & $\mathrm{VC}$ \\
\hline Pulicaria undulata (L.) C. A. Mey & 0 & 39.3 & 10.9 & 2.2 & SA & 0.12 & $\mathrm{VC}$ \\
\hline Panicum turgidum Forssk. & 0 & 3.6 & 15.2 & 8.7 & $\mathrm{M}+\mathrm{SA}$ & 0.08 & $\mathrm{C}$ \\
\hline Ochradenus baccatus Delile & 18.2 & 0 & 2.2 & 6.5 & SA & 0.06 & $\mathrm{C}$ \\
\hline Pergularia tomentosa $\mathrm{L}$. & 13.6 & 10.7 & 2.2 & 0 & SA & 0.05 & $\mathrm{C}$ \\
\hline Suaeda monoica Forssk. ex J. F. Gmel. & 0 & 7.1 & 2.2 & 6.5 & $\mathrm{SA}+\mathrm{SZ}$ & 0.04 & $\mathrm{O}$ \\
\hline Cleome droserifolia (Forssk.) Delile & 4.5 & 0 & 4.3 & 6.5 & $\mathrm{SA}+\mathrm{IT}$ & 0.04 & $\mathrm{O}$ \\
\hline \multicolumn{8}{|l|}{ Perennial Herbs } \\
\hline Citrullus colocynthis (L.) Schrad. & 22.7 & 35.7 & 32.6 & 0 & $\mathrm{M}+\mathrm{SA}+\mathrm{IT}$ & 0.21 & $\mathrm{D}$ \\
\hline Phragmites australis (Cav.) Trin. ex Steud. & 18.2 & 3.6 & 0 & 13 & PAN & 0.08 & $\mathrm{C}$ \\
\hline Monsonia heliotropioides (Cav.) Boiss. & 0 & 3.6 & 10.9 & 2.2 & SA & 0.05 & $\mathrm{C}$ \\
\hline \multicolumn{8}{|l|}{ Annual Herbs } \\
\hline Morettia philaeana (Delile) DC. & 31.8 & 60.7 & 39.1 & 0 & SA & 0.3 & $\mathrm{D}$ \\
\hline Schouwia purpurea (Forssk.) Schweinf. & 9.1 & 35.7 & 8.7 & 0 & SA & 0.11 & $\mathrm{VC}$ \\
\hline Trichodesma africanum (L.) R. Br. & 22.7 & 25 & 4.3 & 0 & $\mathrm{SA}+\mathrm{SZ}$ & 0.1 & $\mathrm{VC}$ \\
\hline Cotula cinerea Delile & 9.1 & 3.6 & 19.6 & 0 & IT & 0.09 & $\mathrm{C}$ \\
\hline Forsskaolea tenacissima $\mathrm{L}$. & 18.2 & 3.6 & 6.5 & 0 & $\mathrm{SA}+\mathrm{SZ}$ & 0.06 & $\mathrm{C}$ \\
\hline $\begin{array}{c}\text { Eremobium aegyptiacum (Spreng.) Asch. \& } \\
\text { Schweinf. ex Boiss. }\end{array}$ & 4.5 & 10.7 & 2.2 & 0 & SA & 0.04 & $\mathrm{O}$ \\
\hline \multicolumn{8}{|l|}{ Species present in two transects } \\
\hline \multicolumn{8}{|l|}{ Trees } \\
\hline Phoenix dactylifera $\mathrm{L}$. & 22.7 & 0 & 0 & 2.2 & $\mathrm{SA}+\mathrm{SZ}$ & 0.04 & $\mathrm{O}$ \\
\hline
\end{tabular}




\begin{tabular}{|c|c|c|c|c|c|c|c|}
\hline 1 & 2 & 3 & 4 & 5 & 6 & 7 & 8 \\
\hline \multicolumn{8}{|l|}{ Shrubs } \\
\hline Farsetia stylosa R. Br. & 0 & 10.7 & 17.4 & 0 & $\mathrm{SA}+\mathrm{SZ}$ & 0.08 & $\mathrm{C}$ \\
\hline Pulicaria incisa (Lam.) DC. & 27.3 & 0 & 4.3 & 0 & SA & 0.06 & $\mathrm{C}$ \\
\hline Senna italica Mill & 0 & 3.6 & 17.4 & 0 & $\mathrm{SA}+\mathrm{SZ}$ & 0.06 & $\mathrm{C}$ \\
\hline Convolvulus hystrix Vahl & 0 & 0 & 2.2 & 8.7 & SA & 0.04 & $\mathrm{O}$ \\
\hline Fagonia indica Burm. F. & 0 & 0 & 6.5 & 2.2 & SA & 0.03 & $\mathrm{O}$ \\
\hline Heliotropium bacciferum Forssk. & 0 & 7.1 & 0 & 2.2 & SA & 0.02 & $\mathrm{O}$ \\
\hline \multicolumn{8}{|l|}{ Perennial Herbs } \\
\hline Cynodon dactylon (L.) Pers. & 13.6 & 0 & 0 & 4.3 & COSM & 0.04 & $\mathrm{O}$ \\
\hline \multicolumn{8}{|l|}{ Annual Herbs } \\
\hline Launaea nudicaulis (L.) Hook. F. & 0 & 0 & 13 & 8.7 & $\mathrm{SA}+\mathrm{IT}$ & 0.07 & $\mathrm{C}$ \\
\hline Asphodelus tenuifolius Cav. & 0 & 7.1 & 15.2 & 0 & $\mathrm{M}+\mathrm{SA}+\mathrm{IT}$ & 0.06 & $\mathrm{C}$ \\
\hline Tribuluspentandrus Forssk. & 0 & 14.3 & 10.9 & 0 & $\mathrm{SA}+\mathrm{SZ}$ & 0.06 & $\mathrm{C}$ \\
\hline Malva parviflora $\mathrm{L}$. & 0 & 0 & 2.2 & 10.9 & $\mathrm{M}+\mathrm{ES}+\mathrm{IT}$ & 0.04 & $\mathrm{O}$ \\
\hline Cleome amblyocarpa Barratte \&Murb. & 0 & 3.6 & 10.9 & 0 & $S A+S Z$ & 0.04 & $\mathrm{O}$ \\
\hline Arnebia hispidissima (Lehm.) DC. & 4.5 & 0 & 0 & 4.3 & SA & 0.02 & $\mathrm{O}$ \\
\hline Euphorbia granulata Forssk. & 0 & 3.6 & 4.3 & 0 & $\mathrm{M}+\mathrm{SA}+\mathrm{IT}$ & 0.02 & $\mathrm{O}$ \\
\hline Reseda pruinosa Delile & 0 & 0 & 2.2 & 2.2 & SA & 0.01 & $\mathrm{O}$ \\
\hline Cistanche phelypaea (L.) Cout. & 4.5 & 3.6 & 0 & 0 & $\mathrm{M}+\mathrm{SA}+\mathrm{IT}$ & 0.01 & $\mathrm{O}$ \\
\hline Tribulus megistopterus Kralik & 4.5 & 0 & 2.2 & 0 & $\mathrm{SA}+\mathrm{SZ}$ & 0.01 & $\mathrm{O}$ \\
\hline \multicolumn{8}{|l|}{ Species present in one transect } \\
\hline \multicolumn{8}{|l|}{ Trees } \\
\hline Balanites aegyptiaca (L.) Delile & 0 & 0 & 28.3 & 0 & $S A+S Z$ & 0.09 & $\mathrm{C}$ \\
\hline Ziziphus spina-christi (L.) Desf. & 18.2 & 0 & 0 & 0 & SA & 0.03 & $\mathrm{O}$ \\
\hline Avicennia marina (Forssk.) Vierh. & 0 & 0 & 0 & 8.7 & SA & 0.03 & $\mathrm{O}$ \\
\hline Ricinus communis $\mathrm{L}$. & 9.1 & 0 & 0 & 0 & PAN & 0.01 & $\mathrm{O}$ \\
\hline Acacia nilotica (L.) Delile & 4.5 & 0 & 0 & 0 & SU & 0.007 & $S$ \\
\hline Capparis decidua (Forssk.) Edgew. & 0 & 0 & 2.2 & 0 & $\mathrm{SA}+\mathrm{SZ}$ & 0.007 & $S$ \\
\hline Hyphaene thebaica (L.) Mart. & 0 & 0 & 0 & 2.2 & $S A+S Z$ & 0.007 & $S$ \\
\hline Moringa peregrina (Forssk.) Fiori & 4.5 & 0 & 0 & 0 & $\mathrm{SZ}+\mathrm{GC}$ & 0.007 & $S$ \\
\hline \multicolumn{8}{|l|}{ Shrubs } \\
\hline Zygophyllum album L. & 0 & 0 & 0 & 26.1 & $\mathrm{M}+\mathrm{SA}+\mathrm{IT}$ & 0.08 & $\mathrm{C}$ \\
\hline Nitraria retusa (Forssk.) Asch. & 0 & 0 & 0 & 26.1 & SA & 0.08 & $\mathrm{C}$ \\
\hline Limonium axillare (Forssk.) Kuntze & 0 & 0 & 0 & 21.7 & $\mathrm{SA}+\mathrm{SZ}$ & 0.06 & $\mathrm{C}$ \\
\hline Crotalaria aegyptiaca Benth. & 0 & 0 & 0 & 10.9 & SZ & 0.04 & $\mathrm{O}$ \\
\hline $\begin{array}{c}\text { Arthrocnemum macrostachyum (Moric.) K. } \\
\text { Koch }\end{array}$ & 0 & 0 & 0 & 13 & $\mathrm{M}+\mathrm{SA}+\mathrm{IT}$ & 0.04 & $\mathrm{O}$ \\
\hline Salvadora persica L. & 0 & 0 & 8.7 & 0 & $\mathrm{SA}+\mathrm{SZ}$ & 0.03 & $\mathrm{O}$ \\
\hline Cornulaca monacantha Delile & 0 & 0 & 0 & 6.5 & SA & 0.02 & $\mathrm{O}$ \\
\hline Artemisia judaica L. & 9.1 & 0 & 0 & 0 & SA & 0.01 & $\mathrm{O}$ \\
\hline Senna holosericea (Freseu) Greuter & 0 & 0 & 4.3 & 0 & SA & 0.01 & $\mathrm{O}$ \\
\hline Fagonia mollis Delile & 9.1 & 0 & 0 & 0 & SA & 0.01 & $\mathrm{O}$ \\
\hline $\begin{array}{c}\text { Iphiona mucronata (Forssk.) Asch. \& } \\
\text { Schweinf. }\end{array}$ & 0 & 7.1 & 0 & 0 & SA & 0.01 & $\mathrm{O}$ \\
\hline Atriplex leucoclada Boiss. & 4.5 & 0 & 0 & 0 & $\mathrm{SA}+\mathrm{IT}$ & 0.007 & $S$ \\
\hline Fagonia bruguieri DC. & 4.5 & 0 & 0 & 0 & $\mathrm{SA}+\mathrm{IT}$ & 0.007 & $S$ \\
\hline Capparis spinosa $\mathrm{L}$. & 0 & 0 & 0 & 2.2 & $\mathrm{M}+\mathrm{SA}+\mathrm{SZ}$ & 0.007 & $S$ \\
\hline Chrozophora oblongifolia (Delile) Spreng. & 4.5 & 0 & 0 & 0 & $\mathrm{M}+\mathrm{SA}$ & 0.007 & $S$ \\
\hline Oxystelma esculentum (L.F.) R. Br. & 0 & 0 & 2.2 & 0 & $\mathrm{SZ}+\mathrm{GC}$ & 0.007 & $S$ \\
\hline $\begin{array}{c}\text { Caroxylon villosum (Schult.) Akhani \& E. } \\
\text { H. Roalson }\end{array}$ & 4.5 & 0 & 0 & 0 & $\mathrm{M}+\mathrm{SA}+\mathrm{IT}$ & 0.007 & $S$ \\
\hline Taverniera aegyptiaca Boiss. & 0 & 0 & 0 & 2.2 & SA & 0.007 & $S$ \\
\hline
\end{tabular}




\begin{tabular}{|c|c|c|c|c|c|c|c|}
\hline 1 & 2 & 3 & 4 & 5 & 6 & 7 & 8 \\
\hline \multicolumn{8}{|l|}{ Perennial Herbs } \\
\hline Aeluropus littoralis (Gouan) Parl. & 0 & 0 & 0 & 6.5 & $\mathrm{M}+\mathrm{IT}$ & 0.02 & $\mathrm{O}$ \\
\hline Imperata cylindrica (L.) Raeusch & 9.1 & 0 & 0 & 0 & PAN & 0.01 & $\mathrm{O}$ \\
\hline Juncus rigidus Desf. & 0 & 0 & 0 & 2.2 & $\mathrm{M}+\mathrm{SA}+\mathrm{IT}$ & 0.007 & $S$ \\
\hline Leptochloa fusca (L.) Kunth & 0 & 0 & 0 & 2.2 & PAL & 0.007 & $S$ \\
\hline $\begin{array}{c}\text { Stipagrostis plumosa (L.) Munro ex T. } \\
\text { Anderson }\end{array}$ & 4.5 & 0 & 0 & 0 & $\mathrm{M}+\mathrm{SA}+\mathrm{IT}$ & 0.007 & $S$ \\
\hline Dichanthum annulatum (Forssk.) Stapf & 4.5 & 0 & 0 & 0 & PAL & 0.007 & $S$ \\
\hline Cyperus rotundus $\mathrm{L}$. & 0 & 0 & 0 & 2.2 & PAN & 0.007 & $S$ \\
\hline Typha domingensis (Pers.) Poir. ex Steud. & 4.5 & 0 & 0 & 0 & PAN & 0.007 & $S$ \\
\hline \multicolumn{8}{|l|}{ Annual Herbs } \\
\hline Astragalus eremophilus Boiss. & 0 & 0 & 30.4 & 0 & SA & 0.1 & $\mathrm{C}$ \\
\hline Hippocrepis constricta Knuze & 0 & 0 & 6.5 & 0 & $\mathrm{M}+\mathrm{SA}+\mathrm{IT}$ & 0.02 & $\mathrm{O}$ \\
\hline Lupinus digitatus Forssk. & 0 & 0 & 6.5 & 0 & M & 0.02 & $\mathrm{O}$ \\
\hline $\begin{array}{c}\text { Polycarpaea robbairea (Kuntze) Greuter \& } \\
\text { Burdet }\end{array}$ & 0 & 0 & 6.5 & 0 & SA & 0.02 & $\mathrm{O}$ \\
\hline Launaea amal-aminae N. Kilian & 0 & 0 & 4.3 & 0 & SA & 0.01 & $\mathrm{O}$ \\
\hline Echium horridum Batt. & 4.5 & 0 & 0 & 0 & SA & 0.007 & $S$ \\
\hline Chenopodium album $\mathrm{L}$. & 4.5 & 0 & 0 & 0 & COSM & 0.007 & $S$ \\
\hline Ch. murale L. & 0 & 0 & 0 & 2.2 & COSM & 0.007 & $S$ \\
\hline Launaea capitata (Spreng.) Dandy & 0 & 0 & 2.2 & 0 & SA & 0.007 & $S$ \\
\hline Filago desertorum Pomel & 4.5 & 0 & 0 & 0 & $\mathrm{SA}+\mathrm{IT}$ & 0.007 & $S$ \\
\hline Glinus lotoides $\mathrm{L}$. & 0 & 0 & 2.2 & 0 & PAL & 0.007 & $S$ \\
\hline $\begin{array}{c}\text { Oligomeris linifolia (Vahl.) ex Hornew J. F. } \\
\text { Macbr. }\end{array}$ & 0 & 0 & 0 & 2.2 & $\mathrm{SA}+\mathrm{SZ}$ & 0.007 & $S$ \\
\hline Sonchus oleraceus L. & 0 & 0 & 0 & 2.2 & COSM & 0.007 & $S$ \\
\hline
\end{tabular}

Tab. 2. Species composition of the obtained 7 vegetation groups, together with their presence values (p\%). Figures in bold are the dominant species that have the highest $\mathrm{p} \%$.

\begin{tabular}{|c|c|c|c|c|c|c|c|}
\hline Vegetation groups & A & B1 & B2 & $\mathrm{C1}$ & $\mathrm{C} 2$ & D1 & D2 \\
\hline Total number of stands & 18 & 18 & 7 & 41 & 8 & 31 & 19 \\
\hline Total number of species & 41 & 26 & 30 & 32 & 19 & 53 & 20 \\
\hline 1 & 2 & 3 & 4 & 5 & 6 & 7 & 8 \\
\hline \multicolumn{8}{|l|}{ Species present in 6 groups } \\
\hline Zilla spinosa & 100 & 94.4 & 100 & & 12.5 & 90.3 & 78.9 \\
\hline Acacia tortilis subsp. raddiana & 38.9 & 77.8 & 71.4 & 19.5 & & 16.1 & 63.2 \\
\hline \multicolumn{8}{|l|}{ Species present in 5 groups } \\
\hline Tamarix aphylla & 16.7 & & & 14.6 & 12.5 & 3.2 & 63.2 \\
\hline Zygophyllum coccineum & 5.6 & & & 7.3 & 100 & 51.6 & 21.1 \\
\hline Aerva javanica & 27.8 & & 14.3 & 12.2 & & 16.1 & 5.3 \\
\hline Pulicaria undulata & 27.8 & 22.2 & & 4.9 & & 9.7 & 15.8 \\
\hline Lotus hebranicus & 27.8 & 5.6 & 57.1 & 7.3 & & 25.8 & \\
\hline \multicolumn{8}{|l|}{ Species present in 4 groups } \\
\hline Citrullus colocynthis & 44.4 & 83.3 & 57.1 & & & 9.7 & \\
\hline Morettia philaeana & 94.4 & 83.3 & 85.7 & & & 12.9 & \\
\hline Pergularia tomentosa & 5.6 & 5.6 & 14.3 & & & 12.9 & \\
\hline Tetraena simplex & 50 & 11.1 & 14.3 & & & 9.7 & \\
\hline Tribulus pentandrus & 27.8 & 11.1 & 14.3 & & & & 5.3 \\
\hline Caroxylon imbricatum & 83.3 & 22.2 & & 2.4 & & 35.5 & \\
\hline Astragalus vogelii & 38.9 & & 85.7 & & & 9.7 & 5.3 \\
\hline Forsskaolea tenacissima & 11.1 & & 28.6 & & & 9.7 & 5.3 \\
\hline Phragmites australis & 11.1 & & & 7.3 & 37.5 & 9.7 & \\
\hline Tamarix nilotica & 5.6 & & & 22 & 100 & 6.5 & \\
\hline
\end{tabular}




\begin{tabular}{|c|c|c|c|c|c|c|c|}
\hline 1 & 2 & 3 & 4 & 5 & 6 & 7 & 8 \\
\hline Malva parviflora & 5.6 & & & 2.4 & & 9.7 & 5.3 \\
\hline Leptadenia pyrotechnica & & 5.6 & & 4.9 & & 12.9 & 15.8 \\
\hline Panicum turgidum & & & 14.3 & 12.2 & & 12.9 & 10.5 \\
\hline \multicolumn{8}{|l|}{ Species present in 3 groups } \\
\hline Asphodelus tenuifolius & 5.6 & 22.2 & 57.1 & & & & \\
\hline Astragalus eremophilus & 11.1 & 33.3 & 85.7 & & & & \\
\hline Cotula cinerea & 16.7 & 16.7 & 85.7 & & & & \\
\hline Monsonia heliotropioides & 11.1 & & 57.1 & & & 3.2 & \\
\hline Pulicaria incise & 11.1 & & 28.6 & & & 12.9 & \\
\hline Schouwia purpurea & 61.1 & & 42.9 & & & 6.5 & \\
\hline Trichodesma africanum & 44.4 & & 14.3 & & & 16.1 & \\
\hline Eremobium aegyptiacum & 16.7 & & 14.3 & & & & 5.3 \\
\hline Farsetia stylosa & 16.7 & & 85.7 & & & & 10.5 \\
\hline Arnebia hispidissima & 5.6 & & & 2.4 & & 3.2 & \\
\hline Fagonia indica & 5.6 & & & 4.9 & & 3.2 & \\
\hline Cynodon dactylon & 5.6 & & & & 25 & 6.5 & \\
\hline Fagonia thebaica & 72.2 & & & & 12.5 & 12.9 & \\
\hline Polycarpaea robbairea & & 5.6 & 14.3 & 2.4 & & & \\
\hline Convolvulus hystrix & & 5.6 & & 2.4 & & 9.7 & \\
\hline Calotropis procera & & 11.1 & & & & 3.2 & 15.8 \\
\hline Launaea nudicaulis & & & 85.7 & 2.4 & & 9.7 & \\
\hline Polycarpaea repens & & & 28.6 & 2.4 & & 12.9 & \\
\hline Nitraria retusa & & & & 17.1 & 50 & & 5.3 \\
\hline Ochradenus baccatus & & & & & 12.5 & 19.4 & 5.3 \\
\hline \multicolumn{8}{|l|}{ Species present in 2 groups } \\
\hline Euphorbia granulata & 11.1 & 5.6 & & & & & \\
\hline Suaeda monoica & 16.7 & & & 7.3 & & & \\
\hline Cistanche phelypaea & 5.6 & & & & & 3.2 & \\
\hline Ricinus communis & 5.6 & & & & & 3.2 & \\
\hline Cleome amblyocarpa & & 11.1 & 57.1 & & & & \\
\hline Hippocrepis constricta & & 5.6 & 28.6 & & & & \\
\hline Lupinus digitatus & & 5.6 & 28.6 & & & & \\
\hline Senna italica & & 44.4 & 14.3 & & & & \\
\hline Artemisia judaica & & 5.6 & & & & 3.2 & \\
\hline Fagonia mollis & & 5.6 & & & & 3.2 & \\
\hline Limonium axillare & & & & 19.5 & 25 & & \\
\hline Zygophyllum album & & & & 24.4 & 25 & & \\
\hline Crotalaria aegyptiaca & & & & 7.3 & & 6.5 & \\
\hline Heliotropium bacciferum & & & & 2.4 & & 6.5 & \\
\hline Reseda pruinosa & & & & 2.4 & & 3.2 & \\
\hline Balanites aegyptiaca & & & & 2.4 & & & 63.2 \\
\hline Cleome droserifolia & & & & & 25 & 12.9 & \\
\hline Phoenix dactylifera & & & & & 12.5 & 16.1 & \\
\hline \multicolumn{8}{|l|}{ Species present in one group } \\
\hline Echium horridum & 5.6 & & & & & & \\
\hline Glinus lotoides & 5.6 & & & & & & \\
\hline Oxystelma esculentum & 5.6 & & & & & & \\
\hline Caroxylon villosum & 5.6 & & & & & & \\
\hline Stipagrostis plumosa & 5.6 & & & & & & \\
\hline Tribulus megistopterus & 11.1 & & & & & & \\
\hline Chenopodium album & & 5.6 & & & & & \\
\hline Filago desertorum & & 5.6 & & & & & \\
\hline
\end{tabular}




\begin{tabular}{|c|c|c|c|c|c|c|c|}
\hline 1 & 2 & 3 & 4 & 5 & 6 & 7 & 8 \\
\hline Launaea capitata & & & 14.3 & & & & \\
\hline L. amal-aminae & & & 28.6 & & & & \\
\hline Aeluropus littoralis & & & & 7.3 & & & \\
\hline Arthrocnemum macrostachyum & & & & 14.6 & & & \\
\hline Avicennia marina & & & & 9.8 & & & \\
\hline Capparis spinosa & & & & 2.4 & & & \\
\hline Cornulaca monacantha & & & & 7.3 & & & \\
\hline Senna holosericea & & & & 4.9 & & & \\
\hline Chenopodium murale & & & & & 12.5 & & \\
\hline Cyperus rotundus & & & & & 12.5 & & \\
\hline Hyphaene thebaica & & & & & 12.5 & & \\
\hline Juncus rigidus & & & & & 12.5 & & \\
\hline Leptochloa fusca & & & & & 12.5 & & \\
\hline Sonchus oleraceus & & & & & 12.5 & & \\
\hline Acacia nilotica & & & & & & 3.2 & \\
\hline Atriplex leucoclada & & & & & & 3.2 & \\
\hline Chrozophora oblongifolia & & & & & & 3.2 & \\
\hline Dichanthum annulatum & & & & & & 3.2 & \\
\hline Fagonia bruguieri & & & & & & 3.2 & \\
\hline Imperata cylindrica & & & & & & 6.5 & \\
\hline Iphiona mucronata & & & & & & 6.5 & \\
\hline Moringa peregrina & & & & & & 3.2 & \\
\hline Oligomeris linifolia & & & & & & 3.2 & \\
\hline Taverniera aegyptiaca & & & & & & 3.2 & \\
\hline Typha domingensis & & & & & & 3.2 & \\
\hline Ziziphus spina-christi & & & & & & 12.9 & \\
\hline Capparis decidua & & & & & & & 5.3 \\
\hline Salvadora persica & & & & & & & 21.1 \\
\hline
\end{tabular}

Tab. 3. Mean values, standard deviations $( \pm \mathrm{SD})$ and ANOVA values of the soil variables in the vegetation groups (A-D2) of the study area. $\mathrm{EC}=$ Electrical conductivity $\left(\mathrm{mS} . \mathrm{cm}^{-1}\right)$, soil fractions (\%), $\mathrm{CS}=$ Coarse sand, $\mathrm{FS}=$ Fine sand, $\mathrm{OM}=$ Organic matter, $\mathrm{Na}^{+}, \mathrm{K}^{+}, \mathrm{Ca}^{+2}, \mathrm{Mg}^{+2}, \mathrm{Cl}^{-}$and $\mathrm{HCO}_{3}$

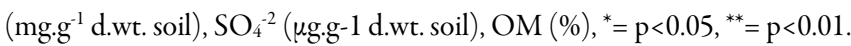

\begin{tabular}{|c|c|c|c|c|c|c|c|c|c|}
\hline \multirow{2}{*}{$\begin{array}{c}\text { Soil } \\
\text { Factors }\end{array}$} & \multirow{2}{*}{$\begin{array}{l}\text { Total } \\
\text { Means }\end{array}$} & \multicolumn{7}{|c|}{ Vegetation groups } & \multirow{2}{*}{ Fvalue } \\
\hline & & A & B1 & B2 & $\mathrm{C} 1$ & $\mathrm{C} 2$ & D1 & D2 & \\
\hline Gravel & $11.27 \pm 10.62$ & $13.03 \pm 10.42$ & $12.03 \pm 8.62$ & $6.91 \pm 3.58$ & $9.56 \pm 10.07$ & $7.44 \pm 14.14$ & $16.22 \pm 11.67$ & $7.76 \pm 9.86$ & $2.223^{*}$ \\
\hline CS & $20.97 \pm 16.48$ & $15.37 \pm 10.64$ & $21.67 \pm 11.86$ & $20.49 \pm 9.31$ & $25.44 \pm 21.94$ & $8.53 \pm 7.56$ & $24.06 \pm 14.88$ & $16.36 \pm 14.60$ & 2.145 \\
\hline FS & $9.31 \pm 6.19$ & $5.59 \pm 2.92$ & $11.40 \pm 7.89$ & $12.83 \pm 4.92$ & $9.70 \pm 6.45$ & $7.58 \pm 6.33$ & $8.39 \pm 5.41$ & $10.99 \pm 6.26$ & $2.421^{* *}$ \\
\hline Silt & $35.52 \pm 16.51$ & $39.59 \pm 13.71$ & $34.16 \pm 13.09$ & $44.85 \pm 9.03$ & $33.44 \pm 17.59$ & $48.35 \pm 14.83$ & $26.38 \pm 12.96$ & $43.52 \pm 19.20$ & $4.36^{* *}$ \\
\hline Clay & $22.91 \pm 18.13$ & $26.43 \pm 13.68$ & $20.74 \pm 19.99$ & $14.93 \pm 6.06$ & $21.86 \pm 19.35$ & $28.10 \pm 14.60$ & $24.95 \pm 23.67$ & $21.37 \pm 9.70$ & 0.592 \\
\hline WC & $2.61 \pm 4.40$ & $1.20 \pm 1.14$ & $1.51 \pm 1.24$ & $1.27 \pm 0.80$ & $5.16 \pm 6.07$ & $5.33 \pm 8.71$ & $1.58 \pm 2.14$ & $0.53 \pm 1.08$ & $5.186^{* *}$ \\
\hline $\mathrm{OM}$ & $1.09 \pm 0.10$ & $1.13 \pm 0.10$ & $1.12 \pm 0.04$ & $1.01 \pm 0.10$ & $1.08 \pm 0.12$ & $1.12 \pm 0.03$ & $1.11 \pm 0.09$ & $1.03 \pm 0.09$ & $3.639^{* *}$ \\
\hline $\mathrm{pH}$ & $7.80 \pm 0.48$ & $8.02 \pm 0.34$ & $7.97 \pm 0.68$ & $7.67 \pm 0.81$ & $7.78 \pm 0.45$ & $7.20 \pm 0.48$ & $7.77 \pm 0.38$ & $7.86 \pm 0.16$ & $3.599^{* *}$ \\
\hline EC & $1.22 \pm 3.35$ & $0.32 \pm 0.11$ & $0.22 \pm 0.05$ & $0.21 \pm 0.05$ & $1.62 \pm 2.27$ & $8.78 \pm 10.77$ & $0.60 \pm 1.00$ & $0.39 \pm 0.51$ & $11.296^{* *}$ \\
\hline $\mathrm{Na}^{+}$ & $0.83 \pm 2.33$ & $0.11 \pm 0.07$ & $0.05 \pm 0.02$ & $0.05 \pm 0.02$ & $1.29 \pm 1.73$ & $5.86 \pm 7.35$ & $0.31 \pm 0.66$ & $0.25 \pm 0.48$ & $10.916^{* *}$ \\
\hline $\mathrm{K}^{+}$ & $0.08 \pm 0.13$ & $0.04 \pm 0.01$ & $0.03 \pm 0.01$ & $0.02 \pm 0.00$ & $0.11 \pm 0.10$ & $0.21 \pm 0.27$ & $0.05 \pm 0.03$ & $0.11 \pm 0.24$ & $3.606^{* *}$ \\
\hline $\mathrm{Ca}^{+2}$ & $0.63 \pm 1.51$ & $0.31 \pm 0.32$ & $0.16 \pm 0.04$ & $0.15 \pm 0.05$ & $0.83 \pm 0.94$ & $3.80 \pm 4.98$ & $0.38 \pm 0.67$ & $0.17 \pm 0.14$ & $9.575^{* *}$ \\
\hline $\mathrm{Mg}^{+2}$ & $0.26 \pm 0.55$ & $0.08 \pm 0.03$ & $0.10 \pm 0.04$ & $0.14 \pm 0.05$ & $0.43 \pm 0.71$ & $1.04 \pm 1.38$ & $0.16 \pm 0.17$ & $0.05 \pm 0.03$ & $5.53^{* *}$ \\
\hline $\mathrm{Cl}^{-}$ & $1.41 \pm 6.04$ & $0.09 \pm 0.07$ & $0.10 \pm 0.03$ & $0.10 \pm 0.03$ & $1.51 \pm 4.12$ & $15.08 \pm 20.02$ & $0.33 \pm 0.81$ & $0.15 \pm 0.18$ & $10.51^{* *}$ \\
\hline $\mathrm{HCO}_{3}^{-}$ & $0.18 \pm 0.06$ & $0.18 \pm 0.05$ & $0.16 \pm 0.05$ & $0.16 \pm 0.08$ & $0.18 \pm 0.06$ & $0.20 \pm 0.12$ & $0.17 \pm 0.05$ & $0.18 \pm 0.04$ & 0.64 \\
\hline $\mathrm{SO}_{4}^{-2}$ & $5.47 \pm 7.36$ & $1.36 \pm 1.24$ & $1.44 \pm 1.66$ & $0.67 \pm 0.96$ & $10.27 \pm 8.27$ & $15.11 \pm 10.12$ & $4.29 \pm 6.64$ & $2.46 \pm 2.68$ & $12.009^{* *}$ \\
\hline
\end{tabular}


53

Tab. 4. Simple linear correlation coefficient $(r)$ between the soil variables and DCA axes. ${ }^{*}=\mathrm{p}<0.05,{ }^{* *}: \mathrm{p}<0.01$. For soil factors abbreviations and units, see Tab. 4.

\begin{tabular}{|c|c|c|}
\hline Soil variables & DCA axis 1 & DCA axis 2 \\
\hline $\mathrm{pH}$ & $-0.167^{*}$ & -0.15 \\
\hline EC & $0.297^{* *}$ & 0.116 \\
\hline $\mathrm{Na}^{+}$ & $0.342^{* *}$ & 0.146 \\
\hline $\mathrm{K}^{+}$ & $0.307^{* *}$ & 0.026 \\
\hline $\mathrm{Ca}^{+2}$ & $0.296^{*}$ & 0.119 \\
\hline $\mathrm{Mg}^{+2}$ & $0.318^{* *}$ & -0.015 \\
\hline $\mathrm{Cl}^{-}$ & $0.217^{* *}$ & 0.098 \\
\hline $\mathrm{HCO}_{3}{ }^{-}$ & 0.119 & 0.072 \\
\hline $\mathrm{SO}_{4}^{-2}$ & $0.612^{* *}$ & $0.172^{*}$ \\
\hline $\mathrm{MC}$ & $0.418^{* *}$ & -0.058 \\
\hline $\mathrm{OM}$ & -0.024 & $0.218^{* *}$ \\
\hline Gravels & $-0.249^{* *}$ & 0.022 \\
\hline CS & 0.034 & -0.111 \\
\hline FS & -0.013 & 0.081 \\
\hline Silt & 0.073 & 0.009 \\
\hline Clay & 0.053 & 0.052 \\
\hline
\end{tabular}

Tab. 5. Floristic diversity between the northern and southern parts of the Eastern Desert. $\left({ }^{1}=\right.$ Data from Abdel Aleem, 2013$)$; T1N= CairoSuez transect; T2N= Korimat-Zaafarana transect, T3N= Sheikh Fadl-Ras Gharib transect; T1S= Qena-Safaga transect; T2S= Idfu-Marsa Alam transect; T3S= Aswan-Kharit-Gimal transect and T4S= Red Sea transect.

\begin{tabular}{|c|c|c|c|c|c|c|c|}
\hline \multirow{2}{*}{ Species } & \multicolumn{3}{|c|}{ North } & \multicolumn{4}{|c|}{ South } \\
\hline & $\mathrm{T} 1 \mathrm{~N}$ & $\mathrm{~T} 2 \mathrm{~N}$ & $\mathrm{~T} 3 \mathrm{~N}$ & T1S & $\mathrm{T} 2 \mathrm{~S}$ & T3S & $\mathrm{T} 4 \mathrm{~S}$ \\
\hline 1 & 2 & 3 & 4 & 5 & 6 & 7 & 8 \\
\hline \multicolumn{8}{|l|}{ Species present in Both Areas } \\
\hline Acacia tortilis (Forssk.) Hayne subsp. raddiana Savi (Brenan) & 35 & 18.2 & 16.7 & 0 & 46.4 & 65.2 & 17.4 \\
\hline Tamarix aphylla (L.) H Karst. & 0 & 0 & 16.7 & 0 & 10.7 & 26.1 & 17.4 \\
\hline Tamarix nilotica (Ehrenb.) Bunge & 40 & 59.1 & 30 & 18.2 & 0 & 4.3 & 30.4 \\
\hline Calotropis procera (Aiton) W. T. Aiton & 30 & 0 & 0 & 4.5 & 7.1 & 6.5 & 0 \\
\hline Zilla spinosa (L.) Prantl. & 95 & 81.8 & 83.3 & 81.8 & 96.4 & 73.9 & 15.2 \\
\hline Zygophyllum coccineum $\mathrm{L}$. & 85 & 63.6 & 83.3 & 59.1 & 3.6 & 8.7 & 30.4 \\
\hline Caroxylon imbricatum (Forssk.) Akhani \& E. H. Roalson & 0 & 22.7 & 40 & 45.5 & 67.9 & 2.2 & 2.2 \\
\hline Aerva javanica (Burm. F.) Juss. ex Schult. & 10 & 0 & 10 & 18.2 & 25 & 8.7 & 4.3 \\
\hline Lotus hebranicus Hochst. ex Brand & 0 & 0 & 6.7 & 13.6 & 14.3 & 17.4 & 13 \\
\hline Leptadenia pyrotechnica (Forssk.) Decne. & 0 & 0 & 10 & 18.2 & 7.1 & 6.5 & 2.2 \\
\hline Pulicaria undulata (L.) C. A. Mey & 50 & 77.3 & 40 & 0 & 39.3 & 10.9 & 2.2 \\
\hline Panicum turgidum Forssk. & 55 & 22.7 & 0 & 0 & 3.6 & 15.2 & 8.7 \\
\hline Suaeda monoica Forssk. ex J. F. Gmel. & 0 & 13.6 & 0 & 0 & 7.1 & 2.2 & 6.5 \\
\hline Ochradenus baccatus Delile & 55 & 59.1 & 56.7 & 18.2 & 0 & 2.2 & 6.5 \\
\hline Cleome droserifolia (Forssk.) Delile & 0 & 0 & 3.3 & 4.5 & 0 & 4.3 & 6.5 \\
\hline Fagonia indica Burm. F. & 20 & 22.7 & 10 & 0 & 0 & 6.5 & 2.2 \\
\hline Heliotropium bacciferum Forssk. & 30 & 4.5 & 6.7 & 0 & 7.1 & 0 & 2.2 \\
\hline Zygophyllum album $\mathrm{L}$. & 0 & 9.1 & 0 & 0 & 0 & 0 & 26.1 \\
\hline Nitraria retusa (Forssk.) Asch. & 0 & 4.5 & 0 & 0 & 0 & 0 & 26.1 \\
\hline Capparis spinosa $\mathrm{L}$. & 0 & 4.5 & 0 & 0 & 0 & 0 & 2.2 \\
\hline Taverniera aegyptiaca Boiss. & 0 & 9.1 & 0 & 0 & 0 & 0 & 2.2 \\
\hline Crotalaria aegyptiaca Benth. & 20 & 0 & 0 & 0 & 0 & 0 & 10.9 \\
\hline Cornulaca monacantha Delile & 5 & 0 & 0 & 0 & 0 & 0 & 6.5 \\
\hline Pergularia tomentosa $\mathrm{L}$. & 25 & 40.9 & 6.7 & 13.6 & 10.7 & 2.2 & 0 \\
\hline Senna italica Mill. & 15 & 0 & 0 & 0 & 3.6 & 17.4 & 0 \\
\hline Pulicaria incisa (Lam.) DC. & 10 & 18.2 & 0 & 27.3 & 0 & 4.3 & 0 \\
\hline Iphiona mucronata (Forssk.) Asch. \& Schweinf. & 20 & 31.8 & 0 & 0 & 7.1 & 0 & 0 \\
\hline Artemisia judaica L. & 5 & 9.1 & 10 & 9.1 & 0 & 0 & 0 \\
\hline
\end{tabular}




\begin{tabular}{|c|c|c|c|c|c|c|c|}
\hline 1 & 2 & 3 & 4 & 5 & 6 & 7 & 8 \\
\hline Fagonia mollis Delile & 25 & 50 & 13.3 & 9.1 & 0 & 0 & 0 \\
\hline Fagonia bruguieri DC. & 30 & 36.4 & 43.3 & 4.5 & 0 & 0 & 0 \\
\hline Atriplex leucoclada Boiss. & 0 & 0 & 6.7 & 4.5 & 0 & 0 & 0 \\
\hline Chrozophora oblongifolia (Delile) Spreng. & 10 & 0 & 0 & 4.5 & 0 & 0 & 0 \\
\hline Phragmites australis (Cav.) Trin. ex Steud. & 10 & 13.6 & 3.3 & 18.2 & 3.6 & 0 & 13 \\
\hline Cynodon dactylon (L.) Pers. & 10 & 0 & 0 & 13.6 & 0 & 0 & 4.3 \\
\hline Leptochloa fusca (L.) Kunth & 0 & 9.1 & 0 & 0 & 0 & 0 & 2.2 \\
\hline Citrullus colocynthis (L.) Schrad. & 5 & 27.3 & 16.7 & 22.7 & 35.7 & 32.6 & 0 \\
\hline Stipagrostis plumosa (L.) Munro ex T. Anderson & 0 & 4.5 & 3.3 & 4.5 & 0 & 0 & 0 \\
\hline Imperata cylindrica (L.) Raeusch & 0 & 13.6 & 0 & 9.1 & 0 & 0 & 0 \\
\hline Tetraena simplex (L.) Beier \& Thulin & 60 & 18.2 & 30 & 9.1 & 28.6 & 8.7 & 2.2 \\
\hline Astragalus vogelii (Webb.) Bornm. & 0 & 9.1 & 10 & 9.1 & 21.4 & 13 & 6.5 \\
\hline Launaea nudicaulis (L.) Hook. F. & 25 & 59.1 & 6.7 & 0 & 0 & 13 & 8.7 \\
\hline Reseda pruinosa Delile & 5 & 4.5 & 10 & 0 & 0 & 2.2 & 2.2 \\
\hline Malva parviflora $\mathrm{L}$. & 15 & 0 & 0 & 0 & 0 & 2.2 & 10.9 \\
\hline Sonchus oleraceus L. & 15 & 45.5 & 0 & 0 & 0 & 0 & 2.2 \\
\hline Chenopodium murale L. & 10 & 0 & 0 & 0 & 0 & 0 & 2.2 \\
\hline Cotula cinerea Delile & 10 & 31.8 & 13.3 & 9.1 & 3.6 & 19.6 & 0 \\
\hline Forsskaolea tenacissima L. & 10 & 4.5 & 10 & 18.2 & 3.6 & 6.5 & 0 \\
\hline Trichodesma africanum (L.) R. Br. & 25 & 40.9 & 20 & 22.7 & 25 & 4.3 & 0 \\
\hline $\begin{array}{c}\text { Eremobium aegyptiacum (Spreng.) Asch. \& Schweinf. ex } \\
\text { Boiss. }\end{array}$ & 0 & 4.5 & 0 & 4.5 & 10.7 & 2.2 & 0 \\
\hline Cleome amblyocarpa Barratte \& Murb. & 25 & 22.7 & 6.7 & 0 & 3.6 & 10.9 & 0 \\
\hline Euphorbia granulata Forssk. & 0 & 9.1 & 0 & 0 & 3.6 & 4.3 & 0 \\
\hline Asphodelus tenuifolius Cav. & 20 & 0 & 0 & 0 & 7.1 & 15.2 & 0 \\
\hline Tribulus megistopterus Kralik & 0 & 4.5 & 0 & 4.5 & 0 & 2.2 & 0 \\
\hline Glinus lotoides L. & 0 & 40.9 & 6.7 & 0 & 0 & 2.2 & 0 \\
\hline Polycarpaea robbairea (Kuntze) Greuter \& Burdet & 0 & 0 & 6.7 & 0 & 0 & 6.5 & 0 \\
\hline Hippocrepis constricta Knuze & 0 & 4.5 & 0 & 0 & 0 & 6.5 & 0 \\
\hline Launaea capitata (Spreng.) Dandy & 0 & 36.4 & 0 & 0 & 0 & 2.2 & 0 \\
\hline Cistanche phelypaea (L.) Cout. & 15 & 31.8 & 6.7 & 4.5 & 3.6 & 0 & 0 \\
\hline Filago desertorum Pomel & 0 & 9.1 & 0 & 4.5 & 0 & 0 & 0 \\
\hline Chenopodium album $\mathrm{L}$. & 5 & 0 & 0 & 4.5 & 0 & 0 & 0 \\
\hline \multicolumn{8}{|l|}{ Species present in Northern Area } \\
\hline Atriplex halimus L. & 15 & 40.9 & 36.7 & 0 & 0 & 0 & 0 \\
\hline Anabasis setifera Moq. & 40 & 31.8 & 33.3 & 0 & 0 & 0 & 0 \\
\hline Farsetia aegyptia Turra & 60 & 50 & 13.3 & 0 & 0 & 0 & 0 \\
\hline Haloxylon salicornicum (Moq.) Bung ex Boiss. & 65 & 59.1 & 56.7 & 0 & 0 & 0 & 0 \\
\hline Launaea spinosa (Forssk.) Sch. Bip. ex Kuntze & 10 & 18.2 & 3.3 & 0 & 0 & 0 & 0 \\
\hline Retama raetam (Forssk.) Webb \& Berthel. & 45 & 27.3 & 13.3 & 0 & 0 & 0 & 0 \\
\hline Hyoscyamus muticus L. & 50 & 22.7 & 3.3 & 0 & 0 & 0 & 0 \\
\hline Senecio glaucus L. & 25 & 36.4 & 3.3 & 0 & 0 & 0 & 0 \\
\hline Astragalus trigonus DC. & 0 & 9.1 & 3.3 & 0 & 0 & 0 & 0 \\
\hline Calligonum polygonoides $\mathrm{L}$. & 0 & 9.1 & 26.7 & 0 & 0 & 0 & 0 \\
\hline Deverra tortuosa (Desf.) DC. & 35 & 0 & 3.3 & 0 & 0 & 0 & 0 \\
\hline Hyoscyamus boveanus (Dunal) Asch. \& Schweinf. & 0 & 0 & 3.3 & 0 & 0 & 0 & 0 \\
\hline Achillea fragrantissima (Forssk.) Sch. Bip. & 5 & 13.6 & 0 & 0 & 0 & 0 & 0 \\
\hline Anabasis articulata (Forssk.) Moq. & 40 & 9.1 & 0 & 0 & 0 & 0 & 0 \\
\hline Cynanchum acutum $\mathrm{L}$. & 15 & 9.1 & 0 & 0 & 0 & 0 & 0 \\
\hline Diplotaxis acris (Forssk.) Boiss. & 10 & 4.5 & 0 & 0 & 0 & 0 & 0 \\
\hline Ephedra alata Decne. & 10 & 9.1 & 0 & 0 & 0 & 0 & 0 \\
\hline Fagonia arabica L. & 10 & 4.5 & 0 & 0 & 0 & 0 & 0 \\
\hline Gymnocarpos decandrus Forssk. & 5 & 9.1 & 0 & 0 & 0 & 0 & 0 \\
\hline Haplophyllum tuberculatum (Forssk.) A. Juss. & 10 & 9.1 & 0 & 0 & 0 & 0 & 0 \\
\hline Lycium shawii Roem. et Schult & 10 & 18.2 & 0 & 0 & 0 & 0 & 0 \\
\hline
\end{tabular}


Nauplius graveolens (Forssk.) Wiklund Rumex vesicarius $\mathrm{L}$.

Reichardia tingitana (L.) Roth

Agathophora alopecuroides (Delile) Fenzl ex Bunge Astragalus sieberi DC.

Cullen plicata (Delile) C. H Stirt.

Helianthemum kahiricum Delile

Reaumuria hirtella Jaub. et Spach Ephedra aphylla Forssk. Artemisia monosperma Delile Convolvulus lanatus Vahl

Helianthemum lipii (L.) Dum-Cours.

Kickxia aegyptiaca (Dum.) Nabelek

Phagnalon barbeyanum Asch. \& Schweinf. Pluchea dioscoridis (L.) DC.

Zygophyllum decumbens Delile

Lavandula coronopifolia Delile

Erodium glaucophyllum (L.) L'Hér. Poirin

Erodium oxyrrhynchum M. Bieb. Lam. Lasiurus scindicus Henrad

Launaea mucronata (Forssk.) Muschl.

Aeluropus lagopoides (L.) Trin. ex Thwaites

Pennisetum divisum (Forssk. ex J. F. Gmel.) Henrard Anastatica hierochuntica L.

Bassia muricata (L.) Asch.

Trigonella stellata Forssk.

Centaurea aegyptiaca L.

Euphorbia retusa Forssk.

Bassia indica (Wight) A.J. Scott Lotus glinoides Delile

Lotononis platycarpa (Viv.) Pic. Serm. Suaeda altissima (L.) Pall. Althaea ludwigii L. Anchusa hispida Forssk.

Diplotaxis harra (Forssk.) Boiss. Centaurea calcitrapa $\mathrm{L}$.

Astragalus bombycinus Boiss.

Conyza bonariensis (L.) Cronquist Echinops spinosissimus Turra Emex spinosa (L.) Campd.

Erodium malacoides (L.) L'Hér.

Matthiola longipetala (Delile) DC. Paronychia arabica (L.) DC. Plantago ovata Forssk.

Pteranthus dichotomus Forssk.

Convolvulus pilosellifolius Desr. Astragalus hamosus L. Astragalus schimperi Boiss. Atractylis mernephtae Asch Avena sterilis L.

Caylusea hexagyna (Forssk.) M.L. Green Crypsis aculeata (DC.) Boiss Herniaria hemistemon J. Gay

Ifloga spicata (Forssk.) Sch.-Bip.

Lappula spinocarpos (Forssk.) Asch. ex Kuntze

\begin{tabular}{|c|c|c|c|c|c|c|}
\hline 2 & 3 & 4 & 5 & 6 & $y$ & 8 \\
\hline 10 & 31.8 & 0 & 0 & 0 & 0 & 0 \\
\hline 30 & 22.7 & 0 & 0 & 0 & 0 & 0 \\
\hline 25 & 18.2 & 0 & 0 & 0 & 0 & 0 \\
\hline 0 & 13.6 & 0 & 0 & 0 & 0 & 0 \\
\hline 0 & 9.1 & 0 & 0 & 0 & 0 & 0 \\
\hline 0 & 4.5 & 0 & 0 & 0 & 0 & 0 \\
\hline 0 & 4.5 & 0 & 0 & 0 & 0 & 0 \\
\hline 0 & 31.8 & 0 & 0 & 0 & 0 & 0 \\
\hline 10 & 0 & 0 & 0 & 0 & 0 & 0 \\
\hline 20 & 0 & 0 & 0 & 0 & 0 & 0 \\
\hline 5 & 0 & 0 & 0 & 0 & 0 & 0 \\
\hline 5 & 0 & 0 & 0 & 0 & 0 & 0 \\
\hline 45 & 0 & 0 & 0 & 0 & 0 & 0 \\
\hline 5 & 0 & 0 & 0 & 0 & 0 & 0 \\
\hline 15 & 0 & 0 & 0 & 0 & 0 & 0 \\
\hline 10 & 0 & 0 & 0 & 0 & 0 & 0 \\
\hline 5 & 4.5 & 0 & 0 & 0 & 0 & 0 \\
\hline 20 & 4.5 & 0 & 0 & 0 & 0 & 0 \\
\hline 10 & 18.2 & 0 & 0 & 0 & 0 & 0 \\
\hline 5 & 18.2 & 0 & 0 & 0 & 0 & 0 \\
\hline 40 & 31.8 & 0 & 0 & 0 & 0 & 0 \\
\hline 0 & 4.5 & 0 & 0 & 0 & 0 & 0 \\
\hline 10 & 0 & 0 & 0 & 0 & 0 & 0 \\
\hline 10 & 40.9 & 16.7 & 0 & 0 & 0 & 0 \\
\hline 30 & 18.2 & 3.3 & 0 & 0 & 0 & 0 \\
\hline 35 & 54.5 & 3.3 & 0 & 0 & 0 & 0 \\
\hline 5 & 13.6 & 10 & 0 & 0 & 0 & 0 \\
\hline 35 & 22.7 & 13.3 & 0 & 0 & 0 & 0 \\
\hline 15 & 0 & 13.3 & 0 & 0 & 0 & 0 \\
\hline 15 & 0 & 3.3 & 0 & 0 & 0 & 0 \\
\hline 0 & 0 & 3.3 & 0 & 0 & 0 & 0 \\
\hline 0 & 0 & 3.3 & 0 & 0 & 0 & 0 \\
\hline 5 & 27.3 & 0 & 0 & 0 & 0 & 0 \\
\hline 20 & 18.2 & 0 & 0 & 0 & 0 & 0 \\
\hline 45 & 36.4 & 0 & 0 & 0 & 0 & 0 \\
\hline 40 & 31.8 & 0 & 0 & 0 & 0 & 0 \\
\hline 10 & 4.5 & 0 & 0 & 0 & 0 & 0 \\
\hline 5 & 4.5 & 0 & 0 & 0 & 0 & 0 \\
\hline 70 & 22.7 & 0 & 0 & 0 & 0 & 0 \\
\hline 5 & 4.5 & 0 & 0 & 0 & 0 & 0 \\
\hline 5 & 9.1 & 0 & 0 & 0 & 0 & 0 \\
\hline 35 & 4.5 & 0 & 0 & 0 & 0 & 0 \\
\hline 10 & 18.2 & 0 & 0 & 0 & 0 & 0 \\
\hline 5 & 27.3 & 0 & 0 & 0 & 0 & 0 \\
\hline 10 & 18.2 & 0 & 0 & 0 & 0 & 0 \\
\hline 0 & 4.5 & 0 & 0 & 0 & 0 & 0 \\
\hline 0 & 4.5 & 0 & 0 & 0 & 0 & 0 \\
\hline 0 & 4.5 & 0 & 0 & 0 & 0 & 0 \\
\hline 0 & 9.1 & 0 & 0 & 0 & 0 & 0 \\
\hline 0 & 4.5 & 0 & 0 & 0 & 0 & 0 \\
\hline 0 & 4.5 & 0 & 0 & 0 & 0 & 0 \\
\hline 0 & 4.5 & 0 & 0 & 0 & 0 & 0 \\
\hline 0 & 4.5 & 0 & 0 & 0 & 0 & 0 \\
\hline 0 & 22.7 & 0 & 0 & 0 & 0 & 0 \\
\hline 0 & 13.6 & 0 & 0 & 0 & 0 & 0 \\
\hline
\end{tabular}




\begin{tabular}{cccccccc}
1 & 2 & 3 & 4 & 5 & 6 & 7 & 8 \\
Morettia philaeana (Delile) DC. & 0 & 0 & 0 & 31.8 & 60.7 & 39.1 & 0 \\
Schouwia purpurea (Forssk.) Schweinf. & 0 & 0 & 0 & 9.1 & 35.7 & 8.7 & 0 \\
Tribulus pentandrus Forssk. & 0 & 0 & 0 & 0 & 14.3 & 10.9 & 0 \\
Astragalus eremophilus Boiss. & 0 & 0 & 0 & 0 & 0 & 30.4 & 0 \\
Lupinus digitatus Forssk. & 0 & 0 & 0 & 0 & 0 & 6.5 & 0 \\
Launaea amal-aminae N. Kilian & 0 & 0 & 0 & 0 & 0 & 4.3 & 0 \\
Echium horridum Batt. & 0 & 0 & 0 & 4.5 & 0 & 0 & 0 \\
\hline
\end{tabular}

\section{References}

Abd El-Ghani MM (1998). Environmental correlates of species distribution in arid desert ecosystems of eastern Egypt. Journal of Arid Environment 38:297-313.

Abd El-Ghani MM (2000). Floristics and environmental relations in two extreme desert zones of western Egypt. Global Ecology and Biogeography 9:499-516.

Abd El-Ghani MM, Amer WM (2003). Soil-vegetation relation-ships in a coastal desert plain of southern Sinai, Egypt. Journal of Arid Environment 55(4):607-28.

Abd El-Ghani MM, Fahmy AG (1998). Composition of and changes in the spontaneous flora of Feiran Oasis, S. Sinai, Egypt, in the last 60 years. Willdenowia 28:123-134.

Abd El-Ghani MM, Salama F, Salem B, El-Hadidy A, AbdelAleem M (2013a)._Biogeographical relations of a hyperarid desert flora in eastern Egypt. African Journal of Ecology (doi/10.1111/aje.12102).

Abd El-Ghani MM, Soliman AT, Hamdy RS, Bennoba IH (2013b). Weed flora in the reclaimed lands along the northern sector of the Nile Valley in Egypt. Turkish Journal of Botany 37:464-488.

Abdel-Aleem M (2013). Floristic analysis and phytogeographical affinities of the Eastern Desert of Egypt. Faculty of Science, Cairo University, Ph D. Diss.

Abu Al-Izz MS (1971). Landforms of Egypt, The American University in Cairo Press, Cairo, $281 \mathrm{p}$.

Allen MM, Stainer ST (1974). Chemical analysis of Ecological Materials, Blackwell Scientific Publications, London, 565 p.

Al-Sherif EA, Ayesh AM, Rawi SM (2013). Floristic composition, life form and chorology of plant life at Khulais region, Western Saudi Arabia. Pakistan Journal of Botany 45(1):2938.

Austin MP (1990). Community theory and competition in vegetation, p. 215-238. In: Grace JB, Tilman D (Eds.). Perspectives on Plant Competition. Academic Press, San Diego.

Bardsley CE, Lancaster JD (1965). Sulfur, p. 1102-1116. In: Black CA, Evans DD, White JL, Jnsminger LE, Clark FE (Eds.). Methods of soil analysis. Part 2. Agronomy. Series No. 9. Madison, Wisconsin: American Society of Agronomy, Inc.

Batalha MA, Martins FR (2002). Life-form spectra of Brazilian cerrado sites. Flora 197:452-460.

Biswas AK (1993). Land resources for sustainable agricultural development in Egypt. Ambio 22:556-560.

Black CA (1979). Methods of soil analysis. American Society of Agronomy 2:771-1572.

Bornkamm R (2001). Allochthonous ecosystems ecosystems without producers. Bocconea 13:201-208.

Bornkamm R, Kehl H (1990). The plant communities of the Western desert of Egypt. Phytocoenologia 19(2):149-231.

Bosabalidis AM (1992). A morphological approach to the question of salt gland lifetime in leaves of Tamarix aphylla L. Israel Journal of Botany 41:115-121.

Boulos L (1995). Flora of Egypt, Check list, Al Hadara Publishing, Cairo, 283 p.

Boulos L (1999). Flora of Egypt, Vol. 1 AzollaceaeOxalidaceae, Al Hadara Publishing, Cairo, 419 p.

Boulos L (2000). Flora of Egypt, Vol. 2 GeraniaceaeBoraginaceae. Al Hadara Publishing, Cairo, Egypt, 293p.

Boulos L (2002). Flora of Egypt, Vol. 3 VerbenaceaeCompositae, Al Hadara Publishing, Cairo, 373 p.

Boulos L (2005): Flora of Egypt, Vol. 4 Monocotyledons (Alismataceae-Orchidaceae), Al Hadara Publishing, Cairo, $617 \mathrm{p}$.

Briggs J, Dickinson G, Murphy K, Pulford I, Belal A, Moalla S, Springuel I, Ghabbour S, Mekki AM (1993). Sustainable development and resource management in marginal environments: natural resources and their use in Wadi Allaqi region of Egypt. Applied Geography 13:259-284.

Bullard JE (1997). Vegetation and dryland morphology, p. 109-131. In: Thomas DSG (Eds.). Arid Zone Geomorphology. J. Wiley and Sons, Chichester.

Da Costa RC, De Araújo FS, Lima-Verde LW (2007). Flora and life-form spectrum in an area of deciduous thorn woodland (caatinga) in northeastern. Journal of Arid Environment 68:237-247.

Dale G (1998). Forest plant diversity at local and landscape scales in the Cascade Mountains of Southwestern Washington. Forest Ecology and Management 109:323341.

Danin A, Shmida A, Liston A (1985). Contribution to the flora of Sinia, III. Checklist of the species collected and recorded by the Jerusalem team 1967-1982. Willdenowia 15(1):255-322.

El-Demerdash MA, Zahran MA, Serag MS (1990). On the ecology of the deltaic Mediterranean coastal land, Egypt. III. The habitat of salt marshes of Damietta-Port Said coastal region. Arab Gulf Journal of Scientific Research 
8(3):103-119.

El Hadidi MN, Fayed AA (1978). Studies on the genus Euphorbia L. in Egypt. II. Systematic treatment. Taeckholmia 9:9-57.

El Hadidi MN, Fayed AA (1995). Materials for excursion flora of Egypt (EFE). Taeckholmia 15:1-233.

Fossati J, Pautou G, Peltier JP (1998). Wadi vegetation of the North-Eastern desert of Egypt. Feddes Repertorium 109:313-327.

Galal TM, Fahmy AG (2011). Plant diversity and community structure of Wadi Gimal protected area, Red Sea Coast of Egypt. African Journal of Ecology 50:266-276.

Gitay H, Noble IR (1997). What are functional types and how should we seek them?, p 3-19. In: Smith TM, Shugart HH, Woodward FI (Eds.). Plant functional types. Cambridge University Press, Cambridge.

Gomaa NH (2012). Soil seed bank in different habitats of the Eastern Desert of Egypt. Saudi Journal of Biological Sciences 19:211-220.

Gouvas M, Theodoropoulos K (2007). Life-form and chorological spectra of the vegetation units of Mount Hymettus (C Greece). Journal of Biological Researchthessaloniki 8:177-187.

Hassib M (1951). Distribution of plant communities in Egypt. Bulletin de l'Institut du Desert d'Egypte 29:60-261.

Hegazy A, Al-Atar AA, Lovett-Doust J, El-Adawy H (2012). Spatial and temporal plant phenological niche differentiation in the Wadi Degla desert ecosystem (Egypt). Acta botanica Croatica 71(2):261-277.

Henderson PA, Seaby RMH (1999). Community Analysis Package (CAP) version 1.2. Pisces Conservation Ltd. IRC House, UK.

Hillel D, Tadmor J (1962). Water regime and vegetation in the central Negev highlands of Israel. Ecology 43:33-41.

Jackson ML (1967). Soil Chemical Analysis-Advanced Course, Department of Soil Sciences, Washington.

Jongman RH, Ter Braak CJF, van Tongeren OFG (1987). Data analysis in community and landscape ecology. Pudoc, Wageningen.

Kapur P, Govil SR (2000). Experimental Plant Ecology $1^{\text {st }}$ Ed. CBS Publishers and Distributors, New Delhi.

Kassas M (1966). Plant life in deserts, p. 145-180. In: Hills ES (Eds.). Arid Lands, London: Mathuen, Parism, UNESCO.

Kassas M, Girgis WA (1965). Habitat and plant communities in the Egyptian desert. VI. The units of desert ecosystem. Journal of Ecology 53:719-729.

Kassas M, Zahran MA (1962). Studies on the ecology of the Red Sea coastal land. I. The district of Gebel Ataqa and ElGalala El-Bahariya. Bulletin Society Geographie d'Egypte 35:129-175.

Klimes L (2003). Life-forms and clonality of vascular plants along an altitudinal gradient in $\mathrm{E}$ Ladakh (NW Himalayas). Basic and Applied Ecology 4:317-328.

Lyon J, Sagers CL (2003). Correspondence analysis of functional groups in a riparian landscape. Plant Ecology
164:171-183.

Mahdavi P, Akhani H, van der Maarel E (2013). Species diversity and life form patterns along $3000 \mathrm{~m}$ altitudinal gradient in the steppe vegetation of southern slopes of the Alborz Mountains, Iran. Folia Geobotanica 48:7-22.

Monod TH (1954). Mode contracte'et diffus de la vegetation Saharienne. p. 35-44. In: Cloudsley-Thompson JL (Eds.). Biology of Desert, Institute of Biology, London.

Moustafa AA, Klopatek JM (1995). Vegetation and landforms of the Saint Catherine area, southern Sinai, Egypt. Journal of Arid Environment 30:385-395.

Moustafa AA, Zaghloul MS (1996). Environment and vegetation in the montane Saint Catherine, south Sinai, Egypt. Journal of Arid Environment 34:331-349.

Noy-Meir I (1973). Desert ecosystems: higher trophic levels. Annual Review of Ecology, Evolution, and Systematics 5: 195-214

Olsvig-Whittaker L, Shachak M, Yair A (1983). Vegetation patterns related to environmental factors in a Negev Desert watershed. Vegetatio 54:153-165.

Orlóci L (1978). Multivariate Analysis in Vegetation Research, $2^{\text {nd }}$ Ed. Dr. W. Junk, The Hague.

Quézel P (1978). Analysis of the flora of Mediterranean and Saharan Africa. Annals of the Missouri Botanical Garden 65:479-534.

Ryan PJ, McKenzie NJ, Loughhead A, Ashton L (1996). New methods for forest soil surveys. In: The role of Eucalyptus and other fast growing species. (Eds.). Eldridge KG, Crowe MP, Olds KM. Csiro Publishing, Collingwood, Victoria.

Said R (1962). The Geology of Egypt, Elsevier, Amsterdam, $377 \mathrm{p}$.

Salama FM, Abd El-Ghani MM, El-Naggar SM, Baayo K (2005). Vegetation structure and environmental gradients in the Sallum area, west Mediterranean, Egypt. Ecologia Mediterranea 31(1):15-32.

Salama FM, Abd El-Ghani MM, El-Tayeh N (2013). Vegetation and soil relationships in the inland wadi ecosystem of central Eastern Desert, Egypt. Turkish Journal of Botany 37:489-498.

Salama FM, Ahmed MK, El-Tayeh NA, Hammad SA (2012). Vegetation analysis, phenological patterns and chorological affinities in Wadi Qena, Eastern Desert, Egypt. African Journal of Ecology 50:193-204.

Salama FM, El-Naggar SM (1991). Phytosociology of wadi system west of Qusseir province. Feddes Repertorium 102:453-468.

Salama FM, Fayed AA (1990). Phytosociological study on the deltaic part and the principal channel of wadi Qena, Egypt. Feddes Repertorium 101:89-95.

Shaheen AM (2002). Weed diversity of newly farmed land on the southern border of Egypt (Eastern and Western shores of Lake Nasser). Pakistan Journal of Biological Sciences 5(7): 802-806.

Shaltout KH, El-Halawany EF, El-Garawany MM (1997). Coastal lowland vegetation of eastern Saudi Arabia. 
Biodiversity and Conservation 6:1027-1070.

Sheded MG, Radwan UA, Taher MA, Springuel I (2012). Spatial heterogeneity in hyper-arid vegetation of the South Western Desert, Egypt. Feddes Repertorium 122(5-6):351366.

Shmida A (1985). Biogeography of the desert flora, p. 149202. In: Evenari M, Noy-Meir I, Goodall DW (Eds.). Ecosystems of the world $12 \mathrm{~B}$ : Hot deserts and arid shrublands, Elsevier, Amsterdam.

Smith T, Huston M (1989). A theory of the spatial and temporal dynamics of plant communities. Vegetatio 83:4969.

Springuel I, Ali MM (1990). Impact of Lake Nasser on desert vegetation in desert development. Proc 2 International Desert Development Conference, Cairo, 557-568.

Springuel I, El-Hadidi MN, Sheded M (1991). Plant communities in southern part of the Eastern Desert (Arabian Desert) of Egypt. Journal of Arid Environment 21:307-317.

Springuel I, Sheded MG, Darius F, Bornkamm R (2006). Vegetation dynamics in an extreme desert wadi under the influence of episodic rainfall. Polish Botanical Studies $22: 495-472$.

Stahr K, Bornkamm R, Gauer A, Kehl H (1985). Veränderung von Boden und Vegetation am Übergang von Halbwüste zur Vollwüste zwischen Mittelmeer und Quattare Depression in Ägypten. Geoökodynamik 6:99-120.

Suzan AS, Gadallah MAA, Salama FM (2013). Ecophysiological studies on three desert plants growing in Wadi Natash, Eastern Desert, Egypt. Journal of Biology and Earth Sciences 3(1):135-143.

Täckholm V (1974). Student's Flora of Egypt, $2^{\text {nd }}$ Ed. Cairo University Press, Cairo, 888 p.

Tielbörger K (1997). The vegetation of linear desert dunes in the north-western Negev, Israel. Flora 192:261-278.

White F (1993). Long distance dispersal and the origins of the afromontane flora. Sonderb. Naturwiss. Vereins Hamburg 7:87-116.

White F, Léonard J (1991). Phytogeographical links between Africa and Southwest Asia. Flora et Vegetatio Mundi 9:229-246

Yair A, Danin A (1980). Spatial variation as related to the soil moisture regime over an arid limestone hillside, northern Negev, Israel. Oecologia 47: 83-88.

Zahran MA, Willis AJ (2009). The Vegetation of Egypt, $2^{\text {nd }}$ Ed. Springer Science and Business Media B.V., London, $541 \mathrm{p}$. 